IZA DP No. 7381

State Merit-Aid Programs and College Major:

A Focus on STEM

David L. Sjoquist

John V. Winters

May 2013 


\title{
State Merit-Aid Programs and College Major: A Focus on STEM
}

\author{
David L. Sjoquist
}

Georgia State University

John V. Winters

University of Cincinnati

and IZA

Discussion Paper No. 7381

May 2013

IZA

P.O. Box 7240

53072 Bonn

Germany

Phone: +49-228-3894-0

Fax: +49-228-3894-180

E-mail: iza@iza.org

Any opinions expressed here are those of the author(s) and not those of IZA. Research published in this series may include views on policy, but the institute itself takes no institutional policy positions. The IZA research network is committed to the IZA Guiding Principles of Research Integrity.

The Institute for the Study of Labor (IZA) in Bonn is a local and virtual international research center and a place of communication between science, politics and business. IZA is an independent nonprofit organization supported by Deutsche Post Foundation. The center is associated with the University of Bonn and offers a stimulating research environment through its international network, workshops and conferences, data service, project support, research visits and doctoral program. IZA engages in (i) original and internationally competitive research in all fields of labor economics, (ii) development of policy concepts, and (iii) dissemination of research results and concepts to the interested public.

IZA Discussion Papers often represent preliminary work and are circulated to encourage discussion. Citation of such a paper should account for its provisional character. A revised version may be available directly from the author. 


\title{
ABSTRACT
}

\section{State Merit-Aid Programs and College Major: A Focus on STEM ${ }^{*}$}

\begin{abstract}
Since 1991 more than two dozen states have adopted merit-based student financial aid programs, intended at least in part to increase the stock of human capital by improving the knowledge and skills of the state's workforce. At the same time, there has been growing concern that the U.S. is producing too few college graduates in science, technology, engineering, and mathematics (STEM) fields. Using both microdata from the American Community Survey and student records from the University System of Georgia, this paper examines whether recently adopted state merit-aid programs have affected college major decisions, with a focus on STEM fields. We find consistent evidence that state merit programs did in fact reduce the likelihood that a young person in the state will earn a STEM degree.
\end{abstract}

JEL Classification: $\quad$ I23, J24

Keywords: merit aid, HOPE scholarship, college major, STEM

Corresponding author:

John V. Winters

Department of Economics

University of Cincinnati

P.O. Box 210371

Cincinnati, OH 45221

USA

E-mail: john.winters@uc.edu

\footnotetext{
* We thank Rob Watts from the Georgia Board of Regents for his assistance in providing data, Lakshmi Pandey for technical assistance, and Bill Even, Barry Hirsch, Larry Katz, and seminar participants at Miami University for helpful comments. The data from the University System of Georgia were provided under a confidential agreement, and thus we cannot make them available; researchers interested in acquiring these data should contact the Georgia Board of Regents. The ACS data and additional results not reported in the paper are available from the authors.
} 


\section{Introduction}

State merit-based financial aid programs, such as Georgia's HOPE Scholarship, award scholarships to in-state students who meet some merit requirement based on high school GPA (for example a 3.0 in Georgia) and sometimes SAT or ACT scores or class rank. State merit aid programs also require students to maintain a certain GPA in college in order to renew the award for subsequent years, although the required GPA differs across programs. ${ }^{1}$ Awards per recipient vary widely, from about $\$ 600$ to over $\$ 8,000$ in $2009-10$, as do grant recipients per full time enrollment, which range from less than 2 percent to over 35 percent (Brookings, 2012). State merit aid programs have grown substantially since the early 1990s and this growth has led to a sizable literature that explores the effects of these programs on college outcomes, including enrollment, persistence, completion, and post-college retention in the state. ${ }^{2}$ One outcome that has received little attention is the effect of merit aid on the choice of college major, and, as we note below, what research has been conducted has limitations. ${ }^{3}$ We explore the effect of merit-

\footnotetext{
${ }^{1}$ The minimum GPA for renewal is typically $2.75-3.0$ but is as low as 2.3 for the first year in Louisiana and 2.5 in subsequent years. A few states also have requirements that students must be continuously enrolled and take a minimum number of credits.

${ }^{2}$ Researchers estimating the effects of state merit-aid programs on college enrollment include Dynarski (2000, 2004); Cornwell et al. (2006); Singell, Waddell and Curs (2006); Goodman (2008); Orsuwan and Heck (2009); Farrell and Kienzl (2009); Zhang and Ness (2010); Winters (2012); Hawley and Rork (2013); and Bruce and Carruthers (2013). This literature typically finds a significantly positive effect on the probability of attending college in-state but inconsistent effects on the overall probability of attending college. Studies of the effects of merit aid on persistence and completion include Dynarski (2008), Sjoquist and Winters (2012a, 2012c), Henry, Rubenstein, and Bugler (HRB) (2004), and Scott-Clayton (2011); Dynarski, HRB and Scott-Clayton find a positive and statistically significant effect on the graduation rate, while Sjoquist and Winters find a small and statistically insignificant effect. Recent working papers by Castleman (2012) and Fitzpatrick and Jones (2012) also examine the effects of merit programs on college degree completion and report mixed results. Studies of post-college in-state retention have been explored by Hickman (2009), Sjoquist and Winters (2012b, 2012d), Fitzpatrick and Jones (2012), and Hawley and Rork (2013). Hu, Trengove, and Zhang (2012) provide a review of this literature. ${ }^{3}$ There is a sizable literature that explores the effect of various factors on the choice of college major, particularly STEM majors. The education literature on choice of major is very large; see Crisp, Nora, and Taggart (2009) and Wang (2012) for surveys of the education literature on this topic. See Delaney (2007) for a more general survey of the literature. Research among economists on the choice of college major dates back to at least Freeman (1971). In a life-cycle framework, the choice of major depends on student preferences, the cost of completing the major, the student's ability, that is, the probability of successfully completing the major course of study, and the expected earnings after graduation (Berger 1988). Montmarquet, Cannings, and Mahseredjian (2002) extend the model to include uncertainty regarding the successful completing of each major; see also Arcidiacono (2004), Griffith (2010),
} 
based aid on the choice of majors using American Community Survey (ACS) data and administrative records from the Georgia Board of Regents, with a particular focus on science, technology, engineering, and mathematics (STEM) majors.

Understanding the effect of merit-based aid on the choice of major is of interest for at least two reasons. First, the choice of major has a significant effect on a student's post-college earnings; see Arcidiacono (2004) and the references therein. Second, from a policy perspective, there is a significant concern that the U.S. is not producing a sufficient number of majors in STEM fields (National Academies 2010). STEM fields are major drivers of innovation and therefore have important consequences for long run economic growth and individual welfare (Atkinson and Mayo 2010). Thus, knowing whether merit-based aid has an unintended consequence of reducing STEM majors is relevant to the national focus on STEM majors.

State merit aid programs could affect student college major decisions through multiple channels. First, Stater (2011) suggests that students choose a college major to maximize expected lifetime utility, which depends on the lifetime net financial return and the non-monetary benefits of a major, given a student's preferences and academic ability. To a given student, some majors may be more enjoyable and offer greater current utility, while others offer higher future earnings and hence higher future utility. Stater argues that an increase in financial aid lowers the price of majors that offer current consumption benefits and encourages student substitution toward such majors. Similarly, financial aid could be viewed as a transitory income shock that could lead to more current consumption oriented majors. ${ }^{4}$ Rothstein and Rouse (2011) suggest

Beffy, Fougere, and Maurel (2011), Arcidiacono, Hotz, and Kang (2012), and Wiswall ad Zafar (2011). Others have considered the effect of academic ability and preparation (see Federman 2007; Griffith 2010; Rash 2010; Ost 2010; Kokkelenberg and Sinha 2010; Stinebrickner and Stinebrickner 2011).

${ }^{4}$ Riegle-Crumb et al. (2012), using the NELS and HS\&B, find that an additional $\$ 10,000$ of real family income reduces the probability that a student will declare a physical science/engineering major by 0.2 to 0.5 percentage points. However, $\$ 10,000$ of permanent family income might have very different effects than transitory income from student financial aid. 
that student loan debt might affect a student's choice of college major and future occupation due to debt aversion and credit constraints. Students who are debt averse may choose high earning majors and occupations to pay off debt quickly after graduation. Post-graduation credit constraints may make it difficult to finance large purchases like cars and houses, and individuals may pursue high earning majors and occupations to make these more attainable. Financial aid should decrease student loan debt and may reduce the importance of future earnings in college major decisions.

While the mechanisms suggested by Stater (2011) and Rothstein and Rouse (2011) apply to financial aid in general, other mechanisms may be unique to state merit aid programs. In particular, Cornwell, Lee, and Mustard (2008) suggest that the requirement that students maintain a 3.0 GPA to retain the HOPE Scholarship in Georgia could cause some students to engage in various strategic behaviors. This could include taking lighter course loads and even majoring in a subject for which it is easier to maintain the required GPA. ${ }^{5}$ Similarly, high school GPA eligibility requirements for merit scholarships may provide incentives for students to take easier courses in high school, which could make them less prepared for more challenging majors in college; alternatively, if merit programs increase student effort in high school, they could cause students to be better prepared for college, which is consistent with the findings of Henry and Rubenstein (2002) and Heller and Rogers (2003). Previous researchers (Dynarski 2000; Cornwell, Mustard, and Sridhar 2006) find that merit programs increase the likelihood that students stay in-state to attend college and affect the type of in-state institution they attend, which could alter the college major options that are available and alter the relative attractiveness of various majors. In particular, merit programs increase the percentage of high ability students

\footnotetext{
${ }^{5}$ Dee and Jackson (1999) find that students in science, engineering, and computing are substantially more likely to lose the Georgia HOPE scholarship than students in other disciplines, but they do not consider the effects that this might have on students' major choices.
} 
who stay in-state, which may make it harder for more moderate ability students to obtain admission to the most selective institutions in the state, which could affect these students' choice of major. Furthermore, if grading is done on a relative basis, merit-induced grade competition from better students may cause moderate ability students to earn lower grades in difficult majors and encourage them to switch to easier majors to stay in college. ${ }^{6}$ Similarly, institutions experiencing increased enrollment due to merit aid may raise standards in STEM fields to push lower ability students into other majors with lower instructional costs.

We identified 4 empirical papers that consider the effects of financial aid on the choice of college major, none of which examine a national microdata sample like the ACS. Stater (2011) considers the effect of student aid on the choice of first-year major using student record data from three large public universities. He finds that loans and grants have small and generally statistically insignificant effects, while merit aid increases the probability of declaring a major in the humanities and in science and reduces the probability of majoring in social sciences. While Stater includes controls for student characteristics, he is unable to control for the endogeneity of aid. Since merit aid is received by students with better academic backgrounds, his merit-aid variable could be reflective of unmeasured student characteristics that affect choice of major. Rothstein and Rouse (2011) explore their supposition using student records from an unidentified, wealthy, highly selective university that adopted a policy that replaced its student loan program with a student grant program. Their difference-in-differences regressions for choice of major yield small and generally statistically insignificant coefficients.

Only two studies have examined the effects of state merit aid programs on college majors. Cornwell, Lee, and Mustard (2008) explore the effect of Georgia's HOPE program on

\footnotetext{
${ }^{6}$ Luppino and Sander (2012) and Arcidiacono, Aucejo, and Hotz (2013) report evidence of peer effects using data from the University of California system. Attending a UC campus where the sciences are more competitive makes a moderate ability student less likely to earn a science degree.
} 
choice of major among freshmen enrolled at the University of Georgia. They find that HOPE had a statistically significant positive effect on the probability of being an education major but no effect on other majors. Zhang (2011) investigates the effect of the Florida and Georgia meritbased aid programs on STEM majors using annual statewide totals of STEM degrees conferred obtained from the Integrated Postsecondary Education Data System's (IPEDS) Completion Survey. He finds no statistically significant effect of merit-based aid on the percentage of STEM majors, except for a 1.6 percentage point increase for private schools in Florida. Using aggregate data on degree conferrals is problematic because merit programs affect where students attend college and have been shown to increase the average quality of students who stay in-state for college. Student quality also affects major choice and needs to be taken into account by using microdata.

We investigate the effect of merit-based financial aid on student choice of college major, focusing especially on STEM majors, using two separate data sets, the American Community Survey (ACS) and administrative data for the University System of Georgia (USG), essentially following the procedures we used in considering the effect of merit-based aid on college completion (Sjoquist and Winters 2012c). Unlike Zhang (2011), who considers the merit-based aid program in only two states, we consider the effects in the 27 states that adopted merit-based aid programs between 1991-2005, although we focus on the 9 states that have more significant merit-aid programs. More importantly, our ACS analysis is unaffected by merit-induced changes in student quality because our merit variable is measured based on state of birth and not state of college attendance. Our USG analysis accounts for merit-aid induced changes in student academic quality by directly controlling for SAT scores and high school attended, as well as sex, race, and ethnicity. Furthermore, our administrative data includes all 35 public colleges and 
universities in Georgia, not just one university as Cornwell, Lee, and Mustard (2008) and Rothstein and Rouse (2011) examine, or just three universities as Stater (2011) considers.

To preview our results, we find a consistent story that significant merit-based aid programs reduce the probability that a young person will complete a bachelor's degree with a STEM major. This is a new and important result in the nascent literature. Using ACS data, our baseline specification suggests that adopting a strong merit-aid program reduces the number of STEM graduates from the state by 6.5 percent, while our baseline specification using the USG data yields an estimate of a 12.9 percent decrease in the number of STEM graduates. The USG data include detailed student information that allows us to take a closer look at which students are shifting away from STEM. Our data do not allow us to identify which of the various mechanisms are driving the negative results, but we do offer some important insights as to which of the possible channels are at work. The decrease in STEM degrees in Georgia appears to be driven largely by the decreased likelihood that initial STEM majors actually go on to earn a STEM degree; HOPE did not significantly affect the likelihood that a student chooses STEM as their initial major. However, HOPE did affect enrollment decisions and appears to have caused a given quality student to enroll in an institution in which they are less likely to earn a STEM degree. We also find evidence that HOPE encouraged students to take actions to increase their GPAs in order to retain HOPE.

\section{Data and Empirical Framework for ACS Analysis}

We consider first the analysis using ACS data. Our interest is in whether merit-based aid affects a student's choice of major, focusing on STEM majors, but also considering the effects on other majors. We use the list of majors that the U.S. Immigration and Customs Enforcement 
uses to define a STEM major. Beginning in 2009, the Census Bureau asked respondents to specify their college major as part of the ACS, and thus, we can use ACS data for 2009-2011 for the analysis. We follow the basic approach used by others that have used Census Bureau data to investigate the effect of merit-based aid on various student outcomes (see Dynarski 2008; Hickman 2009; and Sjoquist and Winters 2012a), and thus provide only a brief explanation below of the data and empirical approach.

We follow a treatment and control research design implemented via a difference-indifferences regression framework. The treatment group consists of individuals who were exposed to a broad-based state merit-aid program when they graduated high school and the control group consists of individuals who were not. Unfortunately, we do not know when and where individuals graduated high school so we follow previous literature (e.g. Dynarski 2008, Hickman 2009, Sjoquist and Winters 2012a) and assign individuals to the merit program treatment group based on state of birth and year of birth, where year of birth is computed as the year of the survey minus age at the time of the survey. If an individual was born in a state that adopted a merit program and turned 18 after the program was implemented, they are assigned to the treatment group; if not, they are part of the control group. The control group, therefore, includes both individuals born in states that never adopted merit programs and individuals born in merit-adopting states but turning 18 before the program was implemented. Because some individuals attend high school outside their state of birth and some do not graduate high school at age 18, our treatment assignment will have some degree of measurement error. We take up the issue of measurement error in more detail later.

Based on various sources (see the footnote to Table 1) we identified 27 states that implemented a merit-based student financial aid program between 1991 and 2005, although the 
characteristics of these programs differ substantially. Some of these state merit-aid programs are relatively small and not likely to have a sizable impact on education outcomes. After reviewing the details of all of these programs, we identified 9 merit-aid programs as being relatively more significant as measured by the eligibility criteria, the number of students in the program, and the size of the award. Table 1 lists characteristics of these 9 "strong" merit-aid states and also lists in a footnote the 18 states adopting "weak" merit aid programs.

We restrict the sample to persons who have at least a bachelor's degree and are between ages 24 and 39 so that every strong merit-aid state has multiple cohorts both before and after the merit-aid program was adopted. We also exclude individuals with imputed information for age, education, college major or state of birth, but results are robust to including these individuals.

Our preferred specification for assessing the effects of broad-based merit scholarship programs on STEM majors is to compare states with strong merit programs to states with no merit program; the District of Columbia is included as a state. We do, however, examine the robustness of our results to including weak merit states in the analysis.

We estimate linear probability models (LPM) as follows:

$$
P\left(Y_{i s c t}=1\right)=\Gamma_{s}+\Pi_{c}+\beta X_{i s c t}+\delta_{s} T_{s c}+\theta \text { Merit }_{s c}+\varepsilon_{i s c t},
$$

where $Y$ equals one if the individual completed a bachelor's degree in a STEM field (either the first or second major), $i$ denotes an individual, $s$ denotes the state of birth, $c$ denotes the year-ofbirth cohort, $t$ denotes the survey year, $\Gamma_{\mathrm{s}}$ includes state-of-birth fixed effects, $\Pi_{c}$ includes yearof-birth cohort fixed effects, $X$ includes dummy variables for individual characteristics including sex, race, Hispanic origin, and age, $T_{s c}$ is state-of-birth by year-of-birth time trends, and Merit is an indicator variable equal to one if the individual was exposed to a state merit program and zero otherwise. The state-of-birth and year-of-birth fixed effects allow the model to be interpreted as 
a difference-in-differences model identified by differences across birth states and across birth cohorts within birth states. We present results for linear models since the coefficients are easier to interpret, but results are robust to using probit or logit. Summary statistics are reported in Table 2 for the full sample and separately for females and males.

Because we use individual level data and the Merit variable is defined based on state and year of birth, OLS standard errors should not be used because they do not account for intracluster correlation (Bertrand, Duflo, and Mullainathan 2004; Donald and Lang 2007; Cameron, Gelbach and Miller 2008). Instead, we report both standard errors clustered by state of birth and 95\% confidence intervals based on procedures suggested by Conley and Taber (2011). Clustered standard errors are typically preferred to OLS standard errors, but Conley and Taber (2011) show that clustered standard errors can be downwardly biased when the number of policy changes is small. They suggest a confidence interval procedure based on the distribution of residuals across the control states and show that their procedure outperforms conventional clustered standard errors when there are a small number of treatment groups and does no worse more generally. Our preferred specification includes 9 states with policy changes, so we report both clustered standard errors and Conley-Taber confidence intervals.

\section{Empirical Results Using the ACS}

\section{III.A. Basic Results}

Table 3 reports our basic results; we report results for the entire sample and separately for females and males. All regressions include dummies for state-of-birth, year-of-birth, age, sex (except for the gender specific regressions), and race/ethnicity, and state-of-birth by year-of-birth time trends. We include state-of-birth by year-of-birth time trends to account for the possibility 
of differential trends in college majors across states. Our preferred specification is in column 1 in which the treatment group includes only persons born in strong merit states who were exposed to a strong merit program; persons born in weak merit states are excluded from both the treated and control states in column 1. The control group thus includes persons born in non-merit states and persons born in strong merit states but reaching age 18 before the merit program was implemented. The remaining columns in Table 3 explore the sensitivity of our results to using different treatment and control states. In the second column persons born in the weak merit-aid states are included as part of the control group. The third column modifies column 1 by including region by year-of-birth dummies; this means that the comparison group includes only states in the same census region. However, strong merit programs were only implemented in the South and West regions so column 3 does not fully utilize information for the Northeast and Midwest regions and Conley-Taber confidence intervals are inestimable because we have too few control states. The fourth column drops all weak merit and non-merit states so that the analysis is simply a pre- and post-merit aid comparison among strong merit-aid states; i.e., the control group includes only persons born in strong merit states but turning age 18 before the program in their state was implemented. The fifth column includes all 51 states in the sample and includes persons exposed to weak merit-aid programs as part of the treatment group.

The results in columns 1-4 of Table 3 tell a consistent story, namely that a strong meritaid program reduces the probability that an individual graduates from college with a STEM major, with the coefficients on the merit variable having similar magnitude across the first 4 columns. The results imply that a strong merit-aid program reduces the probability of graduating with a STEM major by about 1.3 percentage points. Given that only one-fifth of all college 
graduates major in a STEM field, the magnitude of the effect is quite large. The results suggest that adopting a strong merit-aid program reduces the number of STEM graduates by 6.5 percent.

It is well known that the choice of major differs by gender, and thus we estimated the regressions separately for females and males (second and third panels in Table 3). The results imply that it is males, and not females, that experience a decrease in the probability of earning a STEM major as the result of the adoption of a strong merit-aid program. While the coefficient on merit aid is negative for females, it is not statistically significantly different from zero. ${ }^{7} \mathrm{~A}$ potential explanation for the gender difference is that females may be less sensitive to the provision of merit aid, which would be consistent with the finding that choice of major by females is less sensitive to future net earnings (Montmarquette, Canning, and Makserdjian [2002]; Freeman and Hirsch [2008]; Wiswall and Zafar [2011]).

In column 5 we include the weak merit-aid states as part of the treated states. For this regression, the coefficients on merit aid are still negative for the entire sample and for males, but they are much smaller in magnitude and not statistically significant, implying that weak merit-aid programs have only a small effect on the probability that students will major in a STEM field. To further explore this, we ran a regression similar to column 1 (but not reported here) except that we excluded the strong merit-aid states and used only the weak merit-aid states as the treated states. The coefficient estimates are small and statistically insignificant. ${ }^{8}$

We also examined the effects of merit programs on STEM majors separately for each individual state. Except for Nevada and Tennessee, we found negative coefficients that ranged

\footnotetext{
${ }^{7}$ Zhang (2011) also finds differential effects of merit aid by gender.

${ }^{8}$ While we list California as having a merit-aid program, the California program requires only a 2.5 GPA and has a maximum income threshold. Thus, one might question whether California should be considered even a weak meritaid state. We re-estimated column 5 but dropped California from the analysis. The resulting coefficient on merit aid is -0.0095 and is statistically significant. Therefore, excluding California increases the coefficient in column 5 but it is still smaller than the coefficient in column 1, confirming that weak merit programs have weaker effects than the strong merit programs.
} 
from -0.0054 to -0.0631 for all of the strong merit states. However, the individual coefficients are noisily estimated, so we do not report them.

\section{III.B. Robustness}

We considered several robustness checks (results are not shown here). We first estimated the equation in column 2 of Table 3 but included the region by year-of-birth dummies. The results are essentially the same as those in column 2. We also estimated column 1 but included several additional state-of-birth control variables measured the year an individual was age $18^{9}$ : cohort size, the state unemployment rate, median household income, the share of the population that is foreign born, mean K-12 pupil-teacher ratio, mean public K-12 expenditures per pupil, and mean SAT scores. It is possible that there are constraints on the possible number of STEM majors, so larger cohorts might negatively affect the probability of being a STEM major. There is some evidence that the mix of majors is related to economic cycles (Bradley 2012), so we included the unemployment rate. In addition, as noted above, the likelihood that someone might major in a STEM field has been found to be negatively related to household income. Orrenius and Zavodny (2013) find that the foreign born share decreases the likelihood that natives major in STEM fields. Finally, education inputs could have changed and altered student preparation for college. ${ }^{10}$ The results from including these additional control variables are essentially the same as those in column 1.

\footnotetext{
${ }^{9}$ Results are robust to instead measuring these variables at age 20 .

${ }^{10}$ We would have preferred to use measures of student high school performance rather than inputs, but other than SAT scores there are no measures that are consistently available by state for the time period we consider. Annual high school graduation rate estimates by state are available from Greene (2005) but only for 1991 to 2002; other than the possible exception of New Jersey the pattern of graduation rates is not consistent with improved education outcomes due to an educational policy.
} 
The results in Table 3 are conditioned on persons earning a bachelor's degree. But meritaid programs could affect the probability of completing a bachelor's degree and alter the postmerit aid composition of college graduates. For example, if merit aid increases degree completion for marginal students and if these students are less likely to major in a STEM field, then not accounting for selection could bias the results. We might observe an erroneous decrease in the likelihood of majoring in STEM among college graduates because the merit-induced additional graduates majored in non-STEM fields. Sjoquist and Winters (2011c) suggest that merit programs had no significant effect on bachelor's degree completion, but the analysis in this paper uses a smaller sample (only the 2009-2011 ACS), so we also examine the effects of merit programs on bachelor's degree completion using the 2009-2011 ACS with the specifications in Table 3. Results are reported in Appendix Table A. Consistent with Sjoquist and Winters (2011c) the estimates are small and statistically insignificant, so selection is unlikely to be an important issue. To address this issue further, we next estimated the effects of merit programs on being a STEM major using a Heckman selection model. We do not have an excluded exogenous variable to predict selection and therefore must rely on functional form for the selection procedure, which has some limitations. The results from the Heckman selection model are qualitatively similar to our preferred specification in Table 3 . The merit coefficient increases in magnitude to -0.0190 , but it is not significantly different from our preferred specification. Thus, if anything, our point estimate of -0.0133 may be overly conservative.

We next estimated column 1 of Table 3 unconditional on education; results are in Appendix Table B. That is, we redefine the sample to include all 24-39 year olds including those with no college degree or even no high school degree. The results are consistent with the results conditioned on earning a bachelor's degree or more, that is, a negative and statistically 
significant coefficient for the total and for males. The coefficients for the STEM variable are now smaller due to the more inclusive sample and smaller sample means, but the implied percentage decrease in STEM graduates is comparably large. For example, the coefficient and sample mean for the total population are -0.0042 and 0.0537 , implying a 7.8 percent decrease in the number of STEM graduates unconditional on education. We also separately estimated the baseline regression conditional on having at least a high school diploma and conditional on at least some college; the estimated decreases in the number of STEM graduates were 6.7 percent and 8.1 percent, respectively.

\section{III.C. Accounting for Measurement Error in Treatment Status}

Table 4 presents results that account for measurement error in treatment status. The results presented in Table 3 are based on the assignment of individuals to the treatment group if they were born in a state that adopted a merit program and turned 18 after the program was implemented. However, some individuals attend high school outside their state of birth and some finish high school before or after age 18. To account for measurement error due to age when finishing high school, the first column of Table 4 excludes from the sample persons who were ages 18 or 19 when a merit program was implemented in their birth state. ${ }^{11}$ The earlier analysis assigns those who were 18 years old when the program was first implemented to the treatment group and those who were 19 years old to the control group. But some who were 18 when the program started could have finished high school a year earlier at age 17 and not been eligible. Similarly, some individuals who were 19 when the program started could have graduated high school at 19 and been eligible for the merit program. Column 1 of Table 4 excludes these "marginal" birth cohorts from the analysis (both treatment and control groups) to

\footnotetext{
${ }^{11}$ Results are similar excluding those who were ages 17 and 20 when the merit program in their state began.
} 
reduce measurement error. The coefficient estimates are now slightly more negative than the preferred specification in column 1 of Table 3, but the difference is small.

We next account for possible measurement error in treatment assignment due to persons attending high school outside their state of birth. ${ }^{12}$ Following Dynarski (2008), we explore measuring merit exposure based on the predicted probability of going to high school in a merit state based on state of birth. Using the sample of 15-17 year olds in the 2000 Census and 20012011 ACS, for each merit state we regress the probability of living in that state during high school on a complete set of state-of-birth dummies. We then use the predicted values and year of birth to compute the probability that an individual was exposed to a merit program. We then replace the merit dummy in our models with the probabilistic merit variable. ${ }^{13}$ Results are reported in column 2 of Table 4 . The coefficient for the full sample increases in magnitude to -0.0174 , which is somewhat larger than that for the baseline specification in column 1 of Table 3 .

The third column of Table 4 combines the correction procedures used for the first two columns to account for measurement error in treatment due to both year of birth and state. This increases the full sample coefficient to -0.0187 , which suggests that strong merit-aid programs decrease the number of STEM graduates by as much as 9.1 percent. Accounting for both selection and the two forms of measurement error (in results not shown) increases the coefficient estimate to -0.0226 , which suggests an 11 percent decrease in the number of STEM graduates. Although the coefficient estimates accounting for measurement error are not statistically significantly different from the baseline specifications, the results suggest that the true effect of state merit-aid programs may be larger than that reported in column 1 of Table 3.

\footnotetext{
1276 percent of 18 year olds in the Census/ACS live in their birth state.

${ }^{13} \mathrm{We}$ account for the effect of using an estimated covariate on the standard error of the estimated coefficient.
} 


\section{III.D. Differing Effects over Time}

The results thus far assume state-of-birth*year-of-birth linear trends and that the effect of strong merit programs is constant over time, but these assumptions could be too strong. We estimated column 1 of Table 3 excluding the state-of-birth*year-of-birth trends. The results are qualitatively the same, although the coefficients are a little smaller than in column 1 of Table 3 , -0.0093 for the total population. However, our inspection of the raw means revealed a pre-merit upward trend in the percentage of college graduates majoring in STEM in strong merit states; results that ignore this trend are likely inaccurate.

One alternative to our baseline assumptions is to conduct an event-style analysis in which we allow the effects of the merit programs to vary over time by including separate merit indicators for each year before and after the policy in event time. This would also embed a placebo test since there should be no effect in the years immediately before the policy. ${ }^{14} \mathrm{We}$ conducted such an analysis in results not shown. The results are qualitatively consistent with our baseline results but are quite noisy and are not reported. Instead, we report results for short, medium, and long run effects of the merit programs by grouping policy years into roughly 4-year intervals. ${ }^{15}$ That is we define 6 policy year groups: the $1^{\text {st }}-4^{\text {th }}$ years of the policy, the $5^{\text {th }}-8^{\text {th }}$ years of the policy, the $9^{\text {th }}$ or more years of the policy, the $1^{\text {st }}-4^{\text {th }}$ years before the policy, the $5^{\text {th }}-8^{\text {th }}$ years before the policy, and the $9^{\text {th }}$ or more years before the policy. We define the $1^{\text {st }}-4^{\text {th }}$ years before the policy as the base period and then create separate strong merit indicators for the other time groups. We then estimate regressions including the 5 indicators instead of one under the

\footnotetext{
${ }^{14}$ In results not shown we also conducted explicit placebo tests by pretending that the states adopting strong merit programs did so 5 years before they actually adopted the programs and estimating the effects of these fake treatments excluding those who were actually treated. Estimating a placebo regression with the specification in column 1 of Table 3 gives a coefficient of -0.0026 that is small and statistically insignificant. Similar null results for placebo tests are found when we vary the placebo adoption year, implying that the significant negative effects we find for the actual treatment are unlikely to have occurred for reasons other than the treatment, strengthening our confidence in the results for the actual treatment.

${ }^{15} \mathrm{We}$ find similar results using three and five year intervals.
} 
same specifications in column 1 of Table 3, except that we do not include the state-of-birth*yearof-birth trends since this exercise is largely intended as an alternative to using trends; ConleyTaber confidence intervals are unavailable. Results are reported in Table 5.

Column 1 of Table 5 presents results for the total population. The coefficients for the two pre-policy periods are negative but not statistically significantly different from the 4-year period immediately before the policy; the earliest period is also more negative than the second. These negative coefficients are consistent with the upward pre-policy trends in strong merit states that motivated our earlier use of state-of-birth*year-of-birth trends. The coefficients for the post-policy periods are all negative and statistically significant. The coefficients for the first two post-policy periods of -0.0136 and -0.0119 are very similar to our baseline estimate in column 1 of Table 3 of -0.0133 . However, the coefficient for the $9^{\text {th }}$ or more years of the policy is -0.0200 , which suggests that the long run effects may be slightly larger than the short- and medium-run effects.

Columns 2 and 3 report results for females and males separately. The female coefficients are negative and statistically insignificant for all time periods. The male coefficients follow the pattern as the total population, but are larger in magnitude and the earliest pre-policy period is now statistically significant.

\section{III.E. Non-STEM Majors}

Although our focus is on STEM majors, we also consider the effect of merit aid on other majors, with the results presented in Table 6 using our preferred specification. We first combined all of the non-STEM majors into 5 broad categories: business, education, health, liberal arts, and social sciences. Given that strong merit-aid programs reduce the probability that an individual majors in a STEM field, there must be an increase in the likelihood of majoring in 
a non-STEM field. Furthermore, examining the effects on other majors may help us understand why merit programs discourage students from being a STEM major.

In a life-cycle framework the choice of major depends on the expected earnings after graduation and the cost of completing the major, given the student's ability and preferences (Berger 1988). Before presenting the regression results, it is useful to consider earnings and cost. Consider first mean earnings for each broad major. We compute national mean earnings for persons age 40-49 since they were not exposed to merit programs; mid-career earnings may also be more relevant than starting salaries (Berger 1988). Mean earnings in 2011 dollars are $\$ 95,389$ for STEM, $\$ 78,122$ for business, $\$ 67,735$ for social sciences, $\$ 58,937$ for health, $\$ 58,823$ for liberal arts, and $\$ 46,169$ for education. While out-of-pocket costs for textbooks, lab fees, etc. do vary by major, the primary additional cost of a STEM major is thought to be the additional time and effort that is required in STEM courses. Arcidiacono, Aucejo, and Spenner (2012) show that at Duke University natural science, engineering, and economics courses are more difficult, are associated with more study time, and have harsher grading standards. There are several studies that find that grades are lower for courses or majors in STEM fields. For example, Betts and Morell (1999) find that students at the University of California, San Diego who majored in engineering or science had lower grade point averages than students in other majors, controlling for student ability, socioeconomic variables, and resources at the student's high school. Rask (2010) reports that average grades in sciences and math courses at an unnamed northeastern liberal arts college are generally lower and have a wider distribution than grades in other courses.

Consider first the results in columns 1-5 of Table 6 , where each regression is separately estimated using our baseline specification. For the total population, we find that other than for education, the coefficients on merit aid are positive but statistically significant only for liberal 
arts and social sciences. The results by gender suggest that the effect on the social science major is driven by the reaction of females to HOPE while the effect on liberal arts is driven by the response of males. The coefficient for education major is negative and statistically significant for the total population but statistically insignificant in the gender specific regressions. The negative coefficient for education is contrary to the expectations implied by Cornwell, Lee, and Mustard (2008); we discuss their findings in more detail in our analysis of the USG results. Interestingly, these results are not strongly consistent with a shift away from high-paying majors and toward low-paying majors as suggested by the mechanisms of Stater (2011) and Rothstein and Rouse (2011). Finding no shift away from business is particularly noteworthy given its relatively high salary.

We next combined the first three broad majors into "professional" majors and the last into "non-professional" majors (columns 6 and 7 of Table 6). ${ }^{16}$ The coefficients for the professional majors are statistically insignificant, although the signs differ by gender. For the non-professional degrees we obtain a positive and statistically significant effect for the total population and for males.

\section{Data and Empirical Framework for University System of Georgia Analysis}

We next explore the effects of the Georgia HOPE Scholarship on college major using administrative data for the University System of Georgia (USG). These data are described in more detail in our paper on post-college, in-state retention (Sjoquist and Winters 2012b).

Descriptive statistics are presented in Table 7. We obtained individual student data for 4 cohorts

\footnotetext{
${ }^{16}$ We use these terms very broadly and should point out that some of the majors in our liberal arts and social sciences groups could rightly be considered professional majors.
} 
of first-time freshmen from the USG Board of Regents. ${ }^{17}$ The data include all Georgia residents who graduated high school in Georgia in 1990, 1991, 1995 and 1996 and matriculated in one of 35 2-year and 4-year USG schools in the summer or fall immediately after high school. Data were obtained for the 1995 and 1996 cohorts instead of the 1993 and 1994 cohorts because these first two post-HOPE cohorts were initially subject to an income cap for eligibility. The 1992 cohort was not included because of concerns that some students could have anticipated HOPE and changed their behavior in anticipation. Of particular importance, we know the major declared as a freshman and the earned major upon graduation. We first consider the effect of HOPE on majoring in a STEM field, and then consider the effects on other broad majors.

We estimate a linear probability model as follows:

$$
P\left(Y_{i t}=1\right)=\beta X_{i t}+\theta \text { PostHOPE } E_{t}+\varepsilon_{i t},
$$

Where $Y$ is an indicator variable equal to one if the individual's major is in a STEM field, $X$ includes dummy variables for sex, race, Hispanic origin, high school attended, SAT score, and high school GPA, and PostHOPE is a dummy equal to one for the 1995-96 cohorts and zero for the 1990-91 cohorts. ${ }^{18}$ Therefore, $\theta$ measures the effect of the HOPE program on the probability of being a STEM major holding student quality and demographics constant. We consider both the major at time of matriculation (initial major) and the final major (earned major) for students who obtained a 4-year degree. Sjoquist and Winters (2012c) use the same preferred specification and confirm that there was no significant effect on degree completion in the USG data.

\footnotetext{
${ }^{17}$ Our agreement with the Board of Regents limited our data request to 4 cohorts of students.

${ }^{18}$ Note that the PostHOPE dummy equals one for all students in the post-HOPE cohort and not just students who received the HOPE Scholarship. We do not have the HOPE GPA needed to determine if pre-HOPE students would have qualified for HOPE had it existed. However, 86 percent of our post-HOPE sample of graduates received HOPE as freshmen as did 92 percent of post-HOPE graduates with initial STEM majors, so the post-HOPE dummy is a reasonably good approximation for HOPE receipt. We also considered an event-style analysis by replacing the post-hope dummy with three dummies for matriculation year. Results, reported in Appendix Table C, are qualitatively similar to using the simple post-HOPE dummy.
} 


\section{Empirical Results Using USG Data}

\section{V.A. Initial STEM Major}

Unlike the ACS data, we can consider both initial majors and earned majors. Columns 14 of Table 8 presents the results for the USG analysis in which the dependent variable is whether a student initially declared a STEM major as a freshman. The first column includes dummies for sex, race, Hispanic origin, and high school attended, but not SAT, high school GPA, or institution. The second column adds SAT dummies, the third adds high school GPA dummies, and the fourth adds dummies for initial USG institution attended. There are important caveats for the last two columns. Sjoquist and Winters (2012b) argue that HOPE caused high school grade inflation for post-HOPE cohorts in Georgia. Inflated high school GPAs for post-HOPE students mean that one should be cautious interpreting results that control for high school GPA because looking at students with the same GPA compares lower quality post-HOPE students to higher quality pre-HOPE students. ${ }^{19}$ Since student quality is positively correlated with the probability of majoring in a STEM field, grade inflation will create a negative bias in $\theta$ when controlling for high school GPA. Furthermore, HOPE likely changed which institution students attend and this may affect their majors. Our primary interest is in the overall effects of HOPE, but controlling for HOPE-induced changes in institution may partial out some of the effect. Our preferred estimates, therefore, do not control for high school GPA or institution, but we also report results that do. SAT score increases are likely to represent actual increases in student quality and should be controlled for, so our preferred specification is the second column that includes all of the controls except for high school GPA and institution. ${ }^{20}$

\footnotetext{
${ }^{19}$ Castleman (2012) also finds that students in Florida take strategic actions to help ensure that their high school GPAs and SAT/ACT scores are above the cutoffs.

${ }^{20}$ Note that the SAT is not part of the HOPE eligibility condition and thus not subject to merit-induced strategic manipulation.
} 
The results in the first column suggest that the HOPE Scholarship program increased the probability of declaring a STEM major as a freshman. The second column in which we control for student quality by adding the SAT score dummies results in a very small negative coefficient that is statistically insignificant. When we add the high school GPA dummies in the third column, the coefficient estimates become larger negatively and statistically significant. Adding institution dummies increases the coefficient and it is now significantly positive though relatively small. However, there are only 4 cohorts so the clustered standard errors should be interpreted with caution. The Conley-Taber procedure is not feasible since we have administrative data for only one state. The results for our preferred specification in column 2 suggest that controlling for changes in student quality using SAT scores HOPE had no meaningful effect on the likelihood that freshmen declared a STEM major. ${ }^{21}$

\section{V.B. Earned STEM Major}

Columns 5-8 of Table 8 report the effects of HOPE on the probability of earning a bachelor's degree in a STEM field. The coefficient on the post-HOPE dummy is statistically insignificant in column 5, but the effect is significantly negative for all regressions in columns 68. For our preferred regression in column 6 , the coefficient of -0.0253 implies that HOPE reduced the number of STEM graduates by 12.9 percent. Controlling for high school GPA again decreases the coefficient. Controlling for institution again makes the coefficient smaller (i.e., less negative).

${ }^{21}$ One limitation of the analysis using the initial major is that a very large percentage of students, almost 40 percent, do not have a declared major. This is much larger than the 19.9 percent reported by Stater (2011) for the three universities in Colorado, Indiana, and Oregon (1994-1996) and 29.5 percent reported by Carruthers and Özek (2012) for 4-year schools in Tennessee. 
While our preferred results do not control for institution (or high school GPA), the change in the coefficients from doing so offers important insights into why HOPE decreased STEM degrees. The increased coefficient on post-HOPE when controlling for institution could be due to differences across colleges in the effect of HOPE on STEM majors; for example, it could be that maintaining a 3.0 GPA could be easier at some colleges so that fewer students shift to other majors in order to maintain the HOPE Scholarship or that some colleges provide more intensive advising, which increases the attachment to the field for initial STEM majors, so that fewer students switch major as a result of HOPE. But the effect could also be due to changes in the pattern of colleges attended. HOPE enticed many of the state's best and brightest high school graduates to stay in-state (Dynarski 2000), which appears to have increased admission standards at institutions like the Georgia Institute of Technology (Georgia Tech) ${ }^{22}$ This could have led to increased competition for grades or increased demands that faculty place on students in courses, leading to reduced STEM majors. HOPE-induced increased competitiveness appears to have pushed more moderate ability students out to institutions at which majoring in STEM is less appealing, perhaps because these schools do not offer engineering majors or have weaker science programs. Alternatively, moderate ability students may have expected to be unable to keep a 3.0 GPA at Georgia Tech and decided to enroll at less competitive institutions to increase their chances of keeping the HOPE Scholarship. However, because other institutions are not as heavily focused on STEM fields as is Georgia Tech, students shifting away from Georgia Tech

\footnotetext{
22 Cornwell and Mustard (2006) note that over the period 1990 to 2003 average SAT scores for Georgia college freshmen increase significantly more than the average for either U.S. or Georgia high school seniors. Average SAT math scores for in-state students increased between our pre and post-HOPE periods by 24 points at Georgia Tech and by 29 points at the University of Georgia, but by only 5 points for all other schools. The share of USG students with high SAT math scores that enrolled at Georgia Tech decreased over the period; 29.3 percent of students with SAT math scores between 600 and 800 attended Georgia Tech in the pre-HOPE period, but only 22.2 percent in the post-HOPE period. One indication of the increased admission standards at Georgia Tech is that the freshman acceptance rate fell from 69 percent in 1990 to 56 percent in 1996 (Office of Institutional Research and Planning 1990, 1996).
} 
are also more likely to shift away from STEM majors. (See Section V.D for analysis by type of college.)

The pattern of coefficients by sex is similar to that using the ACS. However, the coefficients for the USG students are larger than that found using the ACS (column 1 of Table 3). For the total population the coefficient is -0.0253 for the USG data compared to -0.0133 for the ACS data. ${ }^{23}$ Furthermore, we get a statistically significant coefficient, but only at the 10 percent level, for females, unlike the results using the ACS. We explored the effect of HOPE on subfields within STEM and found that the results reported above are not being driven by a particular subfield.

\section{V.C. Changing Majors}

Our preferred specification in Table 8 suggests that the HOPE Scholarship did not affect the initial choice of a STEM major, but did negatively affect the probability of earning a STEM degree. We explore the relationship between the initial major and the earned major, considering just two categories of majors, STEM and non-STEM. The upper panel of Table 9 is a simple crosstab between initial major and earned major, while the second panel shows for each of the two initial majors the fraction of students with earned degrees with STEM and non-STEM majors. (Table 9 considers only students who earned a college degree.) Note that 13.7 percent of students with an undeclared initial major earned a STEM degree, while only 8.4 percent of students who declared a non-STEM major as a freshman earned a degree with a STEM major. In other words, few students switched into a STEM major during their college career. On the other

\footnotetext{
${ }^{23}$ Recall, however, that accounting for measurement error increases the ACS coefficient somewhat, and the USG does not include private colleges and universities, so we should not be surprised that the ACS and USG estimates differ.
} 
hand, 57.4 percent of students with an initial STEM major actually earned a STEM degree, so that 42.6 percent of freshmen STEM majors switched to another major before they graduated.

Given this pattern it is of interest to consider the effect of the HOPE Scholarship on the student's earned major given the student's initial major (Table 10). Column 1 of Table 10 reproduces column 6 from Table 8, and is presented for convenience. Column 2 considers students who declared a STEM major as a freshman. The results imply, as we would expect, that the HOPE Scholarship caused a reduction in the percentage of initial STEM majors who earned a degree in a STEM field. The coefficients are statistically significant for the entire sample as well as for females and males. The magnitude of the effect of the HOPE Scholarship is larger for initial STEM majors than for the entire sample (column 1), and is larger for males than females.

Columns 3 and 4 examine the effects of HOPE on earning a STEM degree for students with an initial non-STEM major and with an initial undeclared major. For these two groups, the coefficient estimates are negative for the total population as well as for females and males separately, but the coefficients are much smaller than for initial STEM majors and they are not statistically significant. Thus, the negative effect of HOPE on STEM degree production is primarily driven by initial STEM majors deciding not to complete degrees in STEM fields. HOPE is somehow causing initial STEM majors to switch away from STEM at some point before they graduate.

\section{V.D. Type of College}

The University System consists of both 2-year and 4-year schools. One might expect that the effect of merit aid would differ between 2-year and 4-year colleges, perhaps because of differences in the type of students who enroll in the two types of schools, so we consider 2-year 
and 4-year colleges separately. Similarly, there are three large research universities, Georgia Institute of Technology, Georgia State University, and the University of Georgia. Given that the culture and other characteristics of large research universities might differ from smaller 4-year colleges, we explore whether there are differences in the effect of HOPE on STEM majors between 4-year non-research colleges and the three research universities. In addition, the Georgia Institute of Technology is the primary engineering school in the University System of Georgia; Georgia Tech accounted for 32.6 percent of STEM degrees in the sample. Given the difference in the environment in an engineering college, we consider the effect of HOPE on STEM majors at Georgia Tech. We assign the student to the school at which they initially enrolled and use the control variables in our preferred specification.

Table 11 considers the effect of HOPE on the probability of earning a STEM degree by type of school. The results for all schools and for just 4-year schools are very similar, and in particular the effect of HOPE is negative. For 4-year non-research schools, the three research universities and for Georgia Tech, the coefficients for HOPE for all students and for males are negative and statistically significant, but the magnitude of the effect is much larger for Georgia Tech and somewhat larger for the research universities than for the 4-year non-research schools. The coefficient for females is statistically insignificant in column 3, but negative and statistically significant in columns 4 and 5. It thus appears that the effect of HOPE on the probability of being a STEM major is greater at research universities and technology schools in particular. ${ }^{24}$

\section{V.E. STEM Persistence by SAT and GPA}

\footnotetext{
${ }^{24}$ This is even despite the evidence presented above that Georgia Tech increased admission standards and is consistent with arguments that Georgia Tech may have increased grading standards in STEM fields.
} 
There is a substantial literature that attempts to explain the choice of a STEM major and the lack of persistence in earning a degree with a STEM major (see the references in footnote 2). The research reports that students with stronger academic ability as measured, for example, by SAT scores or initial grades in STEM courses, are more likely to initially major in a STEM field and to persist (Ost [2010]; Rask [2010]). Here we consider the effect of HOPE on earned STEM degrees for initial STEM majors by SAT math score and by college GPA using our preferred specification. We measure GPA after one year of college (that is, after 45 quarter credit hours).

Table 12 presents the results by SAT math score ${ }^{25}$; for each panel, the first row is the coefficient on the post-HOPE dummy, the second row in parentheses is the standard error, the third row in brackets is the fraction of students in the SAT category with an initial STEM major who earn a STEM degree in the pre-HOPE period ${ }^{26}$, and the fourth row in braces is the implied percentage change in STEM degrees, that is, row one divided by row three. The coefficients on the post-HOPE dummy are generally negative and are statistically significant for higher SAT math scores. HOPE reduced the probability that an initial STEM major would have an earned STEM degree, and the percentage of students who fail to get a STEM degree due to HOPE is smaller for higher SAT score students. This is not unexpected given existing research that finds that students with higher SAT scores are more likely to initially major in STEM and are more likely to persist and earn a STEM degree. Thus, we expect these students to be less influenced by HOPE. However, while we observe the same pattern for males, for females the relationship is reversed, with the larger percentage change being for females with high SAT math scores. It

\footnotetext{
${ }^{25}$ A few individuals do not have SAT scores. Examination of their GPAs shows that they are on average low performing students, so we include them in the lowest SAT group.

${ }^{26}$ Though not the focus of our study, the simple means are consistent with previous literature suggesting that STEM persistence rates increase with student ability and are generally lower for women than men.
} 
should be of concern for policymakers that HOPE appears to reduce the probability of earning a STEM degree even for students with high SAT math scores.

The results by first-year GPA are presented in Table 13, which parallels the format of Table 12. The coefficients are negative, with one exception, but less than half are statistically significant. There is no consistent pattern in the size of the coefficients on HOPE or the percentage change in the number of students who fail to earn a STEM degree because of HOPE. The results suggest that the HOPE Scholarship reduced the probability of an earned STEM major regardless of first-year GPA, and that in general the magnitude of the effect does not depend on the first-year GPA. Cornwell, Lee, and Mustard $(2005,2008)$ suggest that the requirement that students maintain a 3.0 GPA in order to retain eligibility for a HOPE Scholarship causes students to engage in strategic behavior, such as taking lighter course loads and changing majors if the student is close to a 3.0 GPA. We do not find a larger effect of HOPE for students with a firstyear GPA near 3.0, but some students may have already changed majors and others may have padded their first year schedule with easier courses. As Ost (2010) reports, grades both push students away from a major and pull them towards a major, and since first year grades are not necessarily in STEM courses, the effect by grade may reflect the pull of grades into non-STEM fields.

A further difficulty with using first year GPAs is that it appears that HOPE led to an increase in grades. Table 14 explores how the post-HOPE dummy affected students' first year GPAs, by category of majors. In general, the results imply that the HOPE Scholarship program increased students' GPAs, but the effects for initial STEM majors who earn STEM degrees are smaller than the effects for initial STEM majors earning degrees in other fields. This suggests that many of the latter group may have already begun taking a non-STEM curriculum. These 
results are consistent with the suggestion that students take action to improve their grades in an attempt to meet HOPE's 3.0 GPA renewal requirement. Because college GPA is subject to various forms of manipulation, it cannot be viewed as an exogenous measure of student ability for our analysis.

\section{V.F. Non-STEM Majors}

Table 15 considers the effect of HOPE on earned non-STEM majors; the upper panel considers all students while the lower panel considers just initial STEM majors. For the full sample, HOPE appears to cause an increase in the probability of majoring in business and in health and a decrease in education and social science majors. The coefficient on the post-HOPE dummy for liberal arts majors is positive but statistically insignificant. There are differences in the pattern by gender. There are some similarities between these results and the results using the ACS. For example, the signs of the coefficients are similar, for the total population the only difference in the signs on the coefficients is for social science. However, the coefficients for the USG data are generally statistically significant, while that is not the case for the ACS results. The large shift toward business in the USG is somewhat surprising given the small effects in the ACS analysis. Furthermore, according to the mechanisms suggested by Stater (2011) and

Rothstein and Rouse (2011), financial aid is expected to shift students away from high paying majors like business.

The bottom panel of Table 15 contains results using just those students who declared a STEM major as a freshman. Table 15 suggests that initial STEM majors who changed major shifted into business and liberal arts, although there are differences in the patterns by gender. 
Cornwell, Lee and Mustard (2008), using data from the University of Georgia, find that HOPE led to an increase in the probability of an initial education major. This leads to an expectation that merit-aid programs would also increase the probability of an earned major in education, but we find that merit aid reduces the probability of an earned major in education, using both the ACS and USG data. To explore this conflict in results, we redid our analysis using just data for the University of Georgia and find that HOPE had no effect on the probability of an earned major in education. Cornwell, Lee, and Mustard (2008), however, consider only initial major. When we consider the initial major for University of Georgia students, we obtain a positive, but statistically insignificant, coefficient on HOPE that is similar in magnitude to that found by Cornwell, Lee, and Mustard. Thus, there may have been a slight positive effect of HOPE on initial education majors for students at the University of Georgia, but there appears to be no effect of HOPE on education degrees conferred.

\section{Summary and Conclusions}

Since 1991 more than two dozen states have created statewide merit-based student financial aid programs. One of the main goals of these programs is usually to improve the quality of the state's workforce by increasing the number of college educated workers in the state. However, these programs could have unintended consequences that are counter to the interests of the state. One concern in particular is that these merit-aid programs may encourage students to alter their college curriculum. Recent years have also witnessed a growing concern in the U.S. that the nation's higher education system is producing an insufficient number of college graduates in the fields of science, technology, engineering, and mathematics (STEM). STEM 
fields are important drivers of innovation and economic growth, and U.S. economic performance may lag behind if there are too few STEM graduates entering the workforce.

Using both microdata from the American Community Survey (ACS) and student records from the University System of Georgia (USG), this paper examines whether recently adopted state merit-based financial aid programs have affected students' college major decisions. We focus on STEM fields but also investigate the effects on other majors. We also differentiate between states with strong merit programs and those with weak ones. Both datasets yield consistent evidence that strong state merit-aid programs significantly reduce the likelihood that a young person will earn a STEM degree. This is a new and important finding. While men are more likely to major in STEM fields, both datasets suggest that the negative effect on STEM degrees is much larger for men than women.

For the ACS analysis, our conservative baseline estimates suggest that strong merit programs reduce the likelihood of earning a STEM degree by 1.3 percentage points, but alternative specifications suggest that the magnitude could be nearly twice that size. STEM fields account for roughly 20 percent of all college graduates, so the baseline estimate corresponds to a 6.5 percent decrease in the number of STEM graduates; alternative estimates suggest the decrease could be as large as 11 percent. Given the importance of STEM majors, this decrease is a major concern for both state and national policymakers.

Our USG analysis uses detailed student records to answer questions that the ACS cannot. Our baseline specification for the USG analysis gives a coefficient of -0.025 , which corresponds to a 12.9 percent decrease in the number of STEM graduates. However, the USG does not include private colleges and universities, so the USG results are not directly comparable to the ACS results. Still, there is much to learn from the USG analysis. We find that although 
Georgia's HOPE Scholarship reduced STEM degree completion, it did not affect the likelihood that a student chose STEM as their initial major. Instead, HOPE appears to have caused some students to change majors out of STEM fields at some point in their college career. Furthermore, the decrease in STEM degrees was driven largely by the decrease in initial STEM majors actually earning a STEM degree (not by fewer students switching into a STEM field) and by the decrease in earned STEM degrees by students enrolled at the state's research universities. The decrease in STEM degrees also occurred throughout the ability distribution, but the relative effects were most pronounced for students with good but unexceptional math skills.

Our finding that merit aid reduces the probability of earning a STEM degree could be consistent with a number of possible mechanisms discussed previously. We are unable to say conclusively which mechanisms are driving the results, but we do offer some insights. STEM degrees pay relatively high salaries and the mechanisms posited by Stater (2011) and Rothstein and Rouse (2011) suggest that financial aid causes students to shift away from high paying majors, though it is unclear how large the expected effects should be. However, business majors also have relatively high salaries and we do not see a shift away from business; in the USG we actually see a strong shift toward business. Additionally, the Stater (2011) and Rothstein and Rouse (2011) mechanisms would suggest a decrease in initial STEM majors, but we observe no such decrease in our USG data. So while we cannot rule out the Stater (2011) and Rothstein and Rouse (2011) mechanisms, they seem unlikely to be the primary explanations for the relatively large decrease in STEM degrees that we find.

Our USG analysis provides support for two other mechanisms. First, the USG results suggest that HOPE induced students of a given academic ability to enroll in institutions that make them less likely to earn a STEM degree. This appears to have resulted in part from merit- 
induced increased selectivity at top universities like Georgia Tech, which pushed out many moderate ability students. However, changes in students' college enrollment decisions could also be driven by another mechanism: students have incentives to alter their education plans in order to keep a 3.0 GPA to retain the HOPE Scholarship. This could motivate some students to attend less challenging institutions and major in less challenging fields. We find that HOPE caused first-year GPAs to increase, which is consistent with students taking actions to improve their grades to try to meet HOPE's 3.0 GPA renewal requirement. These actions likely included changing majors away from STEM fields because STEM fields are on average more difficult than other majors. 


\section{References}

Arcidiacono, Peter (2004). "Ability Sorting and the Returns to College Major." Journal of Econometrics 121 (1-2): 343-375.

Arcidiacono, Peter, Esteban M. Aucejo, and V. Joseph Hotz (2013). "University Differences in the Graduation of Minorities in STEM Fields: Evidence from California.” NBER Working Paper No. 18799.

Arcidacono, Peter, Esteban M. Aucejo, and Ken Spenner (2012). "What Happens After Enrollment? An Analysis of the Time Path of Racial Differences in GPA and Major Choice." IZA Journal of Labor Economics 1(5): 1-24.

Arcidiacono, Peter, V. Joseph Hotz, and Songman Kang (2012). "Modeling College Major Choices Using Elicited Measures of Expectations and Counterfactuals." Journal of Econometrics 166 (1): 3-16.

Atkinson, Robert D. and Merrilea Mayo (2010). Refueling the U.S. Innovation Economy: Fresh Approaches to Science, Technology, Engineering and Mathematics (STEM) Education. Information Technology and Innovation Foundation Report.

Beffy, Magali, Denis Fougere, and Arnaud Maurel (2012). "Choosing the Field of Study in PostSecondary Education: Do Expected Earnings Matter?" The Review of Economics and Statistics 94 (1): 334-347.

Berger, Mark (1988). "Predicted Future Earnings and Choice of College Major.” Industrial and Labor Relations Review, 41(3): 418-29.

Bertrand, Marianne, Esther Duflo, and Sendhil Mullainathan (2004). "How Much Should We Trust Differences-in-Differences Estimates?” Quarterly Journal of Economics 119(1):249-75.

Betts, Julian R, and Darlene Morell (1999). The determinants of undergraduate grade point average: The relative importance of family background, high school resources, and peer group effects. Journal of Human Resources 34 (Spring): 268-93.

Bradley, Elizabeth S. (2013). "The Effect of the Business Cycle on Freshman Major Choice." Working paper, Department of Economics, University of Georgia.

Bruce, Donald J. and Celeste K. Carruthers (2013). “Jackpot? The Impact of Lottery Scholarships on Enrollment in Tennessee." Working paper, University of Tennessee. 
Cameron, A. Colin, Jonah B. Gelbach, and Douglas L. Miller (2008). "Bootstrap-Based Improvements for Inference with Clustered Errors." Review of Economics and Statistics 90(3):414-27.

Carruthers, Celeste K. and Umut Özek (2012). "Losing HOPE: Financial Aid and the Line Between College and Work.” Working Paper, University of Tennessee.

Castleman, Benjamin L. (2012). "All or Nothing: The Impact of Partial vs. Full Merit Scholarships on College Entry and Success.” Working Paper, Harvard University.

Conley, Timothy G., and Christopher R. Taber (2011). "Inference with 'Difference in Differences' with a Small Number of Policy Changes." Review of Economics and Statistics 93(1):113-25.

Cornwell, Christopher M., Kyung Hee Lee, and David B. Mustard (2005). "Student Responses to Merit Scholarship Retention Rules.” Journal of Human Resources 40(4): 895-917.

Cornwell, Christopher M., Kyung Hee Lee, and David B. Mustard (2008). "The Effects of StateSponsored Merit Scholarships on Course Selection and Major Choice in College." Working Paper, University of Georgia.

Cornwell, Christopher, David B. Mustard, and Deepa Sridhar (2006). "The Enrollment Effects of Merit-Based Financial Aid: Evidence from Georgia's HOPE Program." Journal of Labor Economics 24(4): 761-86.

Cornwell, Christopher and David Mustard (2006) “Assessing Public Higher Education in Georgia at the Start of the 21st Century" in Ronald Ehrenberg (ed), What's Happening to Public Higher Education.Westport CT: Praeger/American Council Series on Higher Education.

Crisp, Gloria, Amaury Nora, and Amanda Taggart (2009). "Student Characteristics, Pre-College, College, and Environmental Factors as Predictors of Majoring in and Earning a STEM Degree: An Analysis of Students Attending a Hispanic Serving Institution.” American Education Research Journal 46(4): 924-942.

Dee, Thomas S. and Linda A. Jackson (1999). "Who Loses HOPE? Attrition from Georgia's College Scholarship Program.” Southern Economic Journal 66(2): 379-390.

Delaney, Jennifer Ann. (2007). The Academic Consequences of State Merit Aid: The Case of Kentucky. Unpublished Ph.D. dissertation. Stanford University. 
Donald, Stephen G., and Kevin Lang (2007). "Inference with Difference-in-Differences and Other Panel Data." Review of Economics and Statistics 89(2):221-33.

Dynarski, Susan (2000). "Hope for Whom? Financial Aid for the Middle Class and Its Impact on College Attendance." National Tax Journal Part 2 53(3):629-61.

Dynarski, Susan (2004). "The New Merit Aid". In College Choices: The Economics of Which College, When College, and How to Pay for It. Caroline M. Hoxby (ed) Chicago: University of Chicago Press. Pp. 63-97.

Dynarski, Susan (2008). "Building the Stock of College-Educated Labor." Journal of Human Resources 43(3):576-610.

Farrell, Patricia L., and Gregory S. Kienzl (2009). "Are State Non-Need, Merit-Based Scholarship Programs Impacting College Enrollment?” Education Finance and Policy, $4(2), 150-174$

Federman, Maya (2007). "State Graduation Requirements, High School Course Taking, and Choosing a Technical College Major." The B.E. Journal of Economic Analysis \& Policy, 7(1): Article 4.

Fitzpatrick, Maria and Damon Jones (2012). "Higher Education, Merit-Based Scholarships and Post-Baccalaureate Migration.” NBER Working Paper 18530.

Freeman, James A. and Barry T. Hirsch (2008). "College Majors and the Knowledge Content of Jobs." Economics of Education Review 27(5): 517-535.

Freeman, Richard (1971). The Market for College-Trained Manpower: Studies in the Economics of Career Choice. Cambridge, MA: Harvard University Press.

Goodman, Joshua (2008). "Who Merits Financial Aid?: Massachusetts' Adams Scholarship" Journal of Public Economics 92: 2121-2131.

Greene, Jay P. and Marcus A. Winters (2005). "Public High School Graduation and CollegeReadiness Rates: 1991-2002.” Education Working Paper No. 8, Center for Civic Innovation at the Manhattan Institute. http://www.manhattaninstitute.org/html/ewp_08.htm, accessed March 12, 2013.

Griffith, Amanda ( 2010). Persistence of Women and Minorities in STEM Field Majors: Is It the School That Matters? Economics of Education Review. 29 (2010): 911-922. 
Hawley, Zackary B. and Jonathan C. Rork (2013). "The Case of State Funded Higher Education Scholarship Plans and Interstate Brain Drain." Regional Science and Urban Economics, Forthcoming, http://dx.doi.org/10.1016/j.regsciurbeco.2012.07.003.

Heller, Donald E. (2004). "State merit scholarship programs: An overview." In Donald E. Heller $\&$ Patricia Marin, State merit scholarship programs and racial inequality (pp. 1-22). Cambridge, MA: The Civil Rights Project, Harvard University.

Heller, Donald E. and Kimberly R. Rogers (2003). "Merit Scholarships and Incentives for Academic Performance." Paper presented at the annual conference of the Association for the Study of Higher Education. Available at: http://scripts.cac.psu.edu/users/d/e/deh29/papers/ASHE_2003_academic_incentives.pdf, accessed April 5, 2013.

Henry, Gary T. and Ross Rubenstein (2002). "Paying for Grades: Impact of Merit-Based Financial Aid on Educational Quality." Journal of Policy Analysis and Management 21 (1): 93-109.

Henry, Gary T., Ross Rubenstein, and Daniel T. Bugler (2004). "Is HOPE Enough? Impacts of Receiving and Losing Merit-Based Financial Aid.” Educational Policy 18(5):686-709.

Hickman, Daniel C. (2009). "The Effects of Higher Education Policy on the Location Decision of Individuals: Evidence from Florida's Bright Futures Scholarship Program." Regional Science and Urban Economics, 39 (5), 553-562.

Hu, Shouping, Matthew Trengove, and Liang Zhang (2012). "Towards a Greater Understanding of the Effects of Merit Aid Programs: Examining Existing Evidence and Exploring Future Research Directions." In John C. Smart and Michael. B. Paulsen (editors), Higher Education: Handbook of Theory and Research, volume 27. Netherlands: Springer: 291334.

Kokkelenberg, Edward C. and Esha Sinha (2010). "Who Succeeds in STEM Studies? An Analysis of Binghamton University Undergraduate Students." Economics of Education Review, 29(6): 935-946.

Luppino, Marc and Richard Sander (2012). "College Major Competitiveness and Attrition from the Sciences." Working Paper, Federal Trade Commission.

Montmarquette, Claude, Kathy Cannings, and Sophie Mahseredjian (2002). "How Do Young People Choose College Majors?" Economics of Education Review, 21(6): 543-556. 
National Academies (2010). Rising Above the Gathering Storm: Rapidly Approaching Category 5: Revised. 2005 "Rising Above the Storm" Committee. Washington, DC: National Academies Press.

Office of Institutional Research and Planning (1990, 1996). Georgia Tech Fact Book. The Georgia Institute of Technology, Atlanta, Georgia.

Orrenius, Pia M., and Madeline Zavodny (2013). "Does Immigration Affect whether U.S. Natives Major in a STEM Field?” Working Paper, Agnes Scott College.

Orsuwan, Meechai, and Ronald H. Heck (2009). "Merit-Based Student Aid and Freshman Interstate College Migration: Testing a Dynamic Model of Policy Change." Research in Higher Education, 50 (1), 24-51.

Ost, Ben (2010). "The Role of Peers and Grades in Determining Major Persistence in the Sciences." Economics of Education Review, 29(6): 923-934.

Rask, Kevin (2010). "Attrition in STEM Fields at a Liberal Arts College: The Importance of Grades and Pre-Collegiate Preferences." Economics of Education Review, 29(6): 892900.

Riegle-Crumb, Catherine, Barbara King, Eric Grodsky, and Chandra Muller (2012). "The More Things Change, the More They Stay the Same? Prior Achievement Fails to Explain Gender Inequality in Entry Into STEM College Majors Over Time." American Educational Research Journal, 49(6): 1048-1073.

Rothstein, Jesse and Cecilia Rouse (2011). "Constrained After College: Student Loans and Early-Career Occupational Choices.” Journal of Public Economics. 95(2011):149-163.

Scott-Clayton, Judith (2011). "On Money and Motivation: A Quasi-experimental Analysis of Financial Incentives for College Achievement.” Journal of Human Resources 46(3): 614646.

Singell, Larry D., Glen R. Waddell, and Bradley R. Curs (2006). "HOPE for the Pell? Institutional Effects in the Intersection of Merit-Based and Need-Based Aid." Southern Economic Journal, 73 (1), 79-99.

Sjoquist, David L., and John V. Winters (2012a). "Building the Stock of College-Educated Labor Revisited." Journal of Human Resources 47(1): 270-285. 
Sjoquist, David L., and John V. Winters (2012b). "The Effects of HOPE on Post-College Retention in the Georgia Workforce" Regional Science and Urban Economics, Forthcoming.

Sjoquist, David L., and John V. Winters (2012c). "State Merit Aid Programs and College Attainment." Working Paper, Georgia State University.

Sjoquist, David L., and John V. Winters (2012d). "Merit Aid and Post-Schooling Retention." Working Paper, Georgia State University.

Stater, Mark (2011). "Financial Aid, Student Background, and the Choice of First-year College Major.” Eastern Economic Journal 37(3): 321-343.

Stinebrickner, Todd R. and Ralph Stinebrickner (2011). "Math or Science? Using Longitudinal Expectations Data to Examine the Process of Choosing a College Major." NBER Working Paper 16869, Cambridge, MA: National Bureau of Economic Research.

Wang, Xueli (2012). "Modeling Student Choice of STEM Fields of Study: Testing a Conceptual Framework of Motivation, High School Learning, and Postsecondary Context of Support." Working Paper, Wisconsin Center for the Advancement of Postsecondary Education, University of Wisconsin-Madison.

Winters, John V. (2012). “Cohort Crowding and Nonresident College Enrollment.” Economics of Education Review, 31(3): 30-40.

Wiswall, Matthew and Basit Zafar (2011). "Determinants of College Major Choice: Identification Using an Information Experiment.” Staff Report no. 500, Federal Reserve Bank of New York.

Zhang, Liang (2011). "Does Merit-Based Aid Affect Degree Production in STEM Fields: Evidence From Georgia and Florida.” Journal of Higher Education, 82(4): 389-415.

Zhang, Liang, and Erik C. Ness. (2010). "Does State Merit-Based Aid Stem Brain Drain?" Educational Evaluation and Policy Analysis, 32 (2), 143-165. 
Table 1: States Adopting Strong Merit Aid Programs

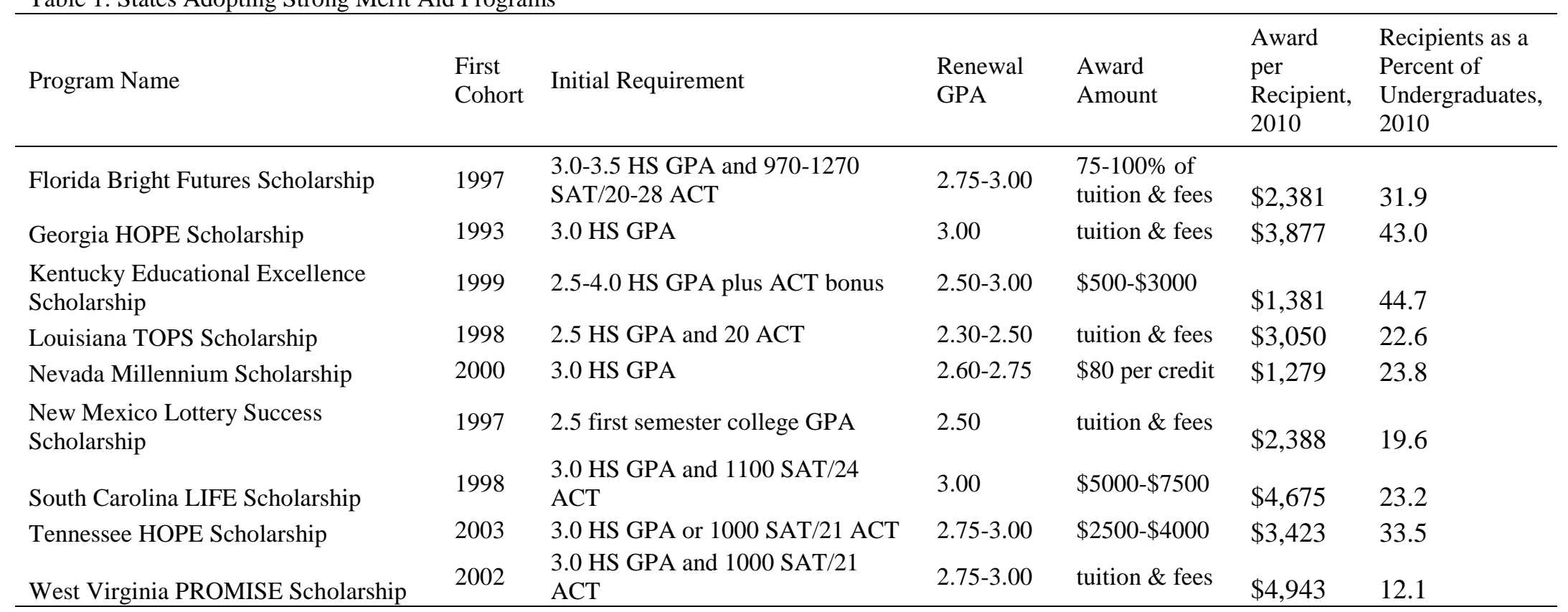

Sources: Dynarski (2004), Heller (2004), the Brookings Institution, and state agency websites.

Note: Eighteen other states adopted "weak" merit aid programs. These include Alaska, Arkansas, California, Idaho, Illinois, Maryland, Massachusetts, Michigan, Mississippi, Missouri, Montana, New Jersey, New York, North Dakota, Oklahoma, South Dakota, Utah, and Washington. For several states the renewal GPA increases after the first renewal point, hence the range given. 
Table 2: Summary Statistics for ACS Data

\begin{tabular}{lcccccr}
\hline & \multicolumn{2}{c}{ All Graduates } & \multicolumn{2}{c}{ Females } & \multicolumn{2}{c}{ Males } \\
& Mean & S.D. & Mean & S.D. & Mean & S.D. \\
\hline STEM Major & 0.206 & 0.405 & 0.137 & 0.344 & 0.294 & 0.455 \\
Business Major & 0.204 & 0.403 & 0.171 & 0.377 & 0.247 & 0.431 \\
Education Major & 0.108 & 0.310 & 0.151 & 0.358 & 0.052 & 0.223 \\
Health Major & 0.056 & 0.230 & 0.086 & 0.280 & 0.018 & 0.133 \\
Liberal Arts Major & 0.237 & 0.425 & 0.243 & 0.429 & 0.228 & 0.420 \\
Social Science Major & 0.189 & 0.391 & 0.211 & 0.408 & 0.160 & 0.367 \\
Strong Merit Dummy & 0.056 & 0.230 & 0.057 & 0.233 & 0.054 & 0.226 \\
Weak Merit Dummy & 0.171 & 0.376 & 0.174 & 0.379 & 0.166 & 0.372 \\
Age & 31.425 & 4.597 & 31.336 & 4.592 & 31.539 & 4.601 \\
Female & 0.559 & 0.496 & 1.000 & 0.000 & 0.000 & 0.000 \\
Black & 0.079 & 0.269 & 0.090 & 0.286 & 0.064 & 0.246 \\
Hispanic & 0.061 & 0.239 & 0.064 & 0.244 & 0.057 & 0.231 \\
Asian & 0.031 & 0.173 & 0.029 & 0.167 & 0.034 & 0.180 \\
Other Non-White & 0.021 & 0.143 & 0.022 & 0.145 & 0.020 & 0.140 \\
Total Observations & 418,739 & 238,395 & & 180,344 \\
\hline Notes: The San
\end{tabular}

Notes: The sample includes all U.S. born college graduates between ages 24 and 39 in the 2009-2011 ACS with un-imputed information for age, education, college major, and birth state. 
Table 3: Merit Program Effects on STEM Majors for Different Treatment and Control States

\begin{tabular}{|c|c|c|c|c|c|}
\hline & (1) & (2) & (3) & (4) & (5) \\
\hline \multirow[t]{3}{*}{ A. Total Population } & -0.0133 & -0.0126 & -0.0122 & -0.0135 & -0.0051 \\
\hline & $(0.0053)^{* *}$ & $(0.0055)^{* *}$ & $(0.0048)^{* *}$ & $(0.0066)^{*}$ & $(0.0047)$ \\
\hline & {$\left[\begin{array}{ll}-0.0261 & -0.0049]\end{array}\right.$} & {$\left[\begin{array}{lll}-0.0237 & -0.0036\end{array}\right]$} & [N/A] & [N/A] & {$\left[\begin{array}{ll}-0.0168 & 0.0034\end{array}\right]$} \\
\hline \multirow[t]{2}{*}{ B. Females } & -0.0057 & -0.0060 & -0.0056 & -0.0055 & 0.0016 \\
\hline & $(0.0093)$ & $(0.0091)$ & $(0.0098)$ & $(0.0103)$ & $(0.0042)$ \\
\hline \multirow[t]{3}{*}{ C. Males } & -0.0240 & -0.0220 & -0.0216 & -0.0244 & -0.0138 \\
\hline & $(0.0099)^{* *}$ & $(0.0088)^{* *}$ & $(0.0101)^{* *}$ & $(0.0079)^{* *}$ & $(0.0086)$ \\
\hline & {$\left[\begin{array}{ll}-0.0468 & -0.0104]\end{array}\right.$} & {$\left[\begin{array}{ll}-0.0400 & -0.0101]\end{array}\right.$} & [N/A] & [N/A] & {$\left[\begin{array}{ll}-0.0317 & 0.0012\end{array}\right]$} \\
\hline State-of-Birth Dummies & Yes & Yes & Yes & Yes & Yes \\
\hline State-of-Birth*Year-of-Birth Trends & Yes & Yes & Yes & Yes & Yes \\
\hline Region*Year-of-Birth Dummies & No & No & Yes & No & No \\
\hline Strong Merit States & Treatment & Treatment & Treatment & Treatment & Treatment \\
\hline Weak Merit States & Excluded & Control & Excluded & Excluded & Treatment \\
\hline Non-Merit States & Control & Control & Control & Excluded & Control \\
\hline Total States & 33 & 51 & 33 & 9 & 51 \\
\hline
\end{tabular}

Notes: Standard errors in parentheses are clustered by state of birth. Conley-Taber $95 \%$ confidence intervals are in brackets; these are inestimable for columns 3 and 4 because of how the control group is specified.

*Significant at $10 \%$ based on standard errors clustered by state of birth; **Significant at $5 \%$. 
Table 4: Merit Program Effects on STEM Majors Accounting for Measurement Error in Treatment Status

\begin{tabular}{|c|c|c|c|}
\hline & $\begin{array}{c}(1) \\
\text { Excluding "Marginal" } \\
\text { Birth Cohorts }\end{array}$ & $\begin{array}{c}(2) \\
\text { Using Probability of } \\
\text { Living in Birth State }\end{array}$ & $\begin{array}{l}\text { (3) } \\
\text { Accounting } \\
\text { for Both }\end{array}$ \\
\hline A. Total Population & $\begin{array}{c}-0.0149 \\
(0.0066)^{* *} \\
{[-0.0282-0.0050]}\end{array}$ & $\begin{array}{c}-0.0174 \\
(0.0069)^{* *} \\
{[-0.0330-0.0057]}\end{array}$ & $\begin{array}{c}-0.0187 \\
(0.0084) * * \\
{[-0.0344 \quad-0.0070]}\end{array}$ \\
\hline B. Females & $\begin{array}{c}-0.0087 \\
(0.0151) \\
{\left[\begin{array}{ll}-0.0192 & 0.0061]\end{array}\right]}\end{array}$ & $\begin{array}{c}-0.0074 \\
(0.0119) \\
{[-0.0192 \quad 0.0071]}\end{array}$ & $\begin{array}{c}-0.0106 \\
(0.0194) \\
{[-0.0231 \quad 0.0038]}\end{array}$ \\
\hline C. Males & $\begin{array}{c}-0.0234 \\
(0.0109)^{* *} \\
{[-0.0494-0.0073]}\end{array}$ & $\begin{array}{c}-0.0316 \\
(0.0127)^{* *} \\
{[-0.0575 \quad-0.0154]}\end{array}$ & $\begin{array}{c}-0.0298 \\
(0.0139)^{* *} \\
{[-0.0612-0.0098]}\end{array}$ \\
\hline State-of-Birth Dummies & Yes & Yes & Yes \\
\hline Year-of-Birth Dummies & Yes & Yes & Yes \\
\hline Age Dummies & Yes & Yes & Yes \\
\hline Sex, Race, and Ethnicity Dummies & Yes & Yes & Yes \\
\hline State-of-Birth Trends & Yes & Yes & Yes \\
\hline Strong Merit States & Treatment & Treatment & Treatment \\
\hline Weak Merit States & Excluded & Excluded & Excluded \\
\hline Non-Merit States & Control & Control & Control \\
\hline
\end{tabular}

Notes: Standard errors in parentheses are clustered by state of birth. Conley-Taber 95\% confidence intervals are in brackets. Column (1) excludes from the sample persons who were age 18 in the year of or year before the merit program was implemented in their birth state. Column (2) measures merit exposure by the predicted probability of going to high school in a merit state based on state of birth. See text for further details.

$*$ Significant at $10 \%$ based on standard errors clustered by state of birth; **Significant at $5 \%$. 
Table 5: Merit Program Effects on STEM Majors for Different Years Before and After Policy

\begin{tabular}{|c|c|c|c|}
\hline & $\begin{array}{c}(1) \\
\text { Total }\end{array}$ & $\begin{array}{c}(2) \\
\text { Females }\end{array}$ & $\begin{array}{c}(3) \\
\text { Males }\end{array}$ \\
\hline 9+ Years Before Policy & $\begin{array}{l}-0.0140 \\
(0.0086)\end{array}$ & $\begin{array}{l}-0.0069 \\
(0.0102)\end{array}$ & $\begin{array}{c}-0.0225 \\
(0.0106) * *\end{array}$ \\
\hline 5-8 Years Before Policy & $\begin{array}{l}-0.0084 \\
(0.0072)\end{array}$ & $\begin{array}{l}-0.0045 \\
(0.0090)\end{array}$ & $\begin{array}{c}-0.0134 \\
(0.0098)\end{array}$ \\
\hline 1-4 Years Before Policy & Base Years & Base Years & Base Years \\
\hline 1st-4th Years of Policy & $\begin{array}{c}-0.0136 \\
(0.0044)^{* * *}\end{array}$ & $\begin{array}{l}-0.0055 \\
(0.0080)\end{array}$ & $\begin{array}{c}-0.0250 \\
(0.0057) * * *\end{array}$ \\
\hline 5th-8th Years of Policy & $\begin{array}{c}-0.0119 \\
(0.0045)^{* *}\end{array}$ & $\begin{array}{l}-0.0016 \\
(0.0063)\end{array}$ & $\begin{array}{c}-0.0255 \\
(0.0061) * * *\end{array}$ \\
\hline 9th+ Years of Policy & $\begin{array}{c}-0.0200 \\
(0.0038)^{* * *}\end{array}$ & $\begin{array}{l}-0.0090 \\
(0.0080)\end{array}$ & $\begin{array}{c}-0.0355 \\
(0.0092) * * *\end{array}$ \\
\hline State of Birth Dummies & Yes & Yes & Yes \\
\hline Year of Birth Dummies & Yes & Yes & Yes \\
\hline Age Dummies & Yes & Yes & Yes \\
\hline Sex, Race/Ethnicity Dummies & Yes & Yes & Yes \\
\hline State of Birth Year Trends & No & No & No \\
\hline Strong Merit States & Treatment & Treatment & Treatment \\
\hline Weak Merit States & Excluded & Excluded & Excluded \\
\hline Non-Merit States & Control & Control & Control \\
\hline Total States & 33 & 33 & 33 \\
\hline
\end{tabular}

Notes: Standard errors in parentheses are clustered by state of birth.

$* *$ Significant at $5 \%$ based on standard errors clustered by state of birth; *** Significant at $1 \%$. 
Table 6: Merit Program Effects on other Broad Majors

\begin{tabular}{|c|c|c|c|c|c|c|c|}
\hline & $\begin{array}{c}(1) \\
\text { Business }\end{array}$ & $\begin{array}{c}(2) \\
\text { Education }\end{array}$ & $\begin{array}{c}\text { (3) } \\
\text { Health-Related }\end{array}$ & $\begin{array}{c}\text { (4) } \\
\text { Liberal Arts }\end{array}$ & $\begin{array}{c}(5) \\
\text { Social Sciences }\end{array}$ & $\begin{array}{c}(6) \\
\text { Professional }\end{array}$ & $\begin{array}{c}(7) \\
\text { Non-Professional }\end{array}$ \\
\hline A. Total Population & $\begin{array}{c}0.0057 \\
(0.0077) \\
{[-0.00430 .0160]}\end{array}$ & $\begin{array}{c}-0.0110 \\
(0.0062)^{*} \\
{[-0.01720 .0010]}\end{array}$ & $\begin{array}{c}0.0003 \\
(0.0054) \\
{[-0.00730 .0070]}\end{array}$ & 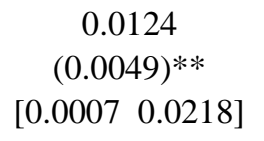 & $\begin{array}{c}0.0058 \\
(0.0031)^{*} \\
{[-0.00310 .0176]}\end{array}$ & $\begin{array}{c}-0.0050 \\
(0.0062) \\
{[-0.01700 .0084]}\end{array}$ & $\begin{array}{c}0.0183 \\
(0.0041)^{* * *} \\
{[0.00590 .0304]}\end{array}$ \\
\hline B. Females & $\begin{array}{c}0.0133 \\
(0.0152) \\
{[-0.00270 .0258]}\end{array}$ & $\begin{array}{c}-0.0145 \\
(0.0107) \\
{[-0.0261 \quad 0.0004]}\end{array}$ & $\begin{array}{c}0.0023 \\
(0.0097) \\
{[-0.00970 .0146]}\end{array}$ & $\begin{array}{c}-0.0083 \\
(0.0088) \\
{\left[\begin{array}{ll}-0.0212 & 0.0071\end{array}\right]}\end{array}$ & $\begin{array}{c}0.0128 \\
(0.0068)^{*} \\
{[-0.00050 .0253]}\end{array}$ & $\begin{array}{c}0.0011 \\
(0.0144) \\
{[-0.01970 .0215]}\end{array}$ & $\begin{array}{c}0.0045 \\
(0.0090) \\
{[-0.01150 .0205]}\end{array}$ \\
\hline C. Males & $\begin{array}{c}-0.0040 \\
(0.0070) \\
{[-0.02090 .0123]}\end{array}$ & $\begin{array}{c}-0.0057 \\
(0.0060) \\
{[-0.01310 .0035]}\end{array}$ & $\begin{array}{c}-0.0022 \\
(0.0049) \\
{[-0.0056 \quad 0.0049]}\end{array}$ & $\begin{array}{c}0.0400 \\
(0.0085)^{* * *} \\
{[0.02000 .0558]}\end{array}$ & $\begin{array}{c}-0.0040 \\
(0.0103) \\
{[-0.01860 .0126]}\end{array}$ & $\begin{array}{c}-0.0119 \\
(0.0092) \\
{[-0.02700 .0100]}\end{array}$ & $\begin{array}{c}0.0359 \\
(0.0100)^{* * *} \\
{[0.01630 .0542]}\end{array}$ \\
\hline State-of-Birth Dummies & Yes & Yes & Yes & Yes & Yes & Yes & Yes \\
\hline Year-of-Birth Dummies & Yes & Yes & Yes & Yes & Yes & Yes & Yes \\
\hline Age Dummies & Yes & Yes & Yes & Yes & Yes & Yes & Yes \\
\hline Sex, Race/Ethnicity Dummies & Yes & Yes & Yes & Yes & Yes & Yes & Yes \\
\hline State-of-Birth Trends & Yes & Yes & Yes & Yes & Yes & Yes & Yes \\
\hline Strong Merit States & Treatment & Treatment & Treatment & Treatment & Treatment & Treatment & Treatment \\
\hline Weak Merit States & Excluded & Excluded & Excluded & Excluded & Excluded & Excluded & Excluded \\
\hline Non-Merit States & Control & Control & Control & Control & Control & Control & Control \\
\hline Total States & 33 & 33 & 33 & 33 & 33 & 33 & 33 \\
\hline
\end{tabular}

Notes: Standard errors in parentheses are clustered by state of birth. Conley-Taber $95 \%$ confidence intervals are in brackets.

*Significant at $10 \%$ based on standard errors clustered by state of birth; **Significant at 5\%; ***Significant at $1 \%$ 
Table 7: Summary Statistics for USG Data

\begin{tabular}{lcccccc}
\hline & \multicolumn{2}{c}{ All Graduates } & \multicolumn{2}{c}{ Females } & \multicolumn{2}{c}{ Males } \\
& Mean & S.D. & Mean & S.D. & Mean & S.D. \\
\hline STEM Major & 0.197 & 0.398 & 0.128 & 0.334 & 0.289 & 0.453 \\
Business Major & 0.261 & 0.439 & 0.213 & 0.410 & 0.324 & 0.468 \\
Education Major & 0.153 & 0.360 & 0.216 & 0.412 & 0.068 & 0.252 \\
Health Major & 0.057 & 0.232 & 0.090 & 0.286 & 0.013 & 0.114 \\
Liberal Arts Major & 0.157 & 0.364 & 0.155 & 0.362 & 0.160 & 0.367 \\
Social Science Major & 0.175 & 0.380 & 0.198 & 0.398 & 0.145 & 0.352 \\
Post-HOPE Dummy & 0.540 & 0.498 & 0.554 & 0.497 & 0.521 & 0.500 \\
SAT Math & 518.4 & 92.8 & 498.9 & 85.8 & 544.3 & 95.4 \\
SAT Verbal & 520.7 & 90.0 & 513.0 & 88.5 & 530.9 & 91.0 \\
High School GPA & 3.037 & 0.620 & 3.092 & 0.600 & 2.963 & 0.639 \\
Female & 0.572 & 0.495 & 1.000 & 0.000 & 0.000 & 0.000 \\
Black & 0.182 & 0.386 & 0.224 & 0.417 & 0.126 & 0.332 \\
Hispanic & 0.010 & 0.102 & 0.010 & 0.099 & 0.011 & 0.105 \\
Asian & 0.029 & 0.167 & 0.026 & 0.159 & 0.033 & 0.177 \\
Native American & 0.002 & 0.039 & 0.001 & 0.038 & 0.002 & 0.040 \\
Observations & 42,399 & \multicolumn{2}{c}{24,263} & & 18,136 \\
\hline
\end{tabular}


Table 8: Effects of HOPE on Choosing a STEM Major

\begin{tabular}{|c|c|c|c|c|c|c|c|c|}
\hline \multirow[b]{3}{*}{ A. Total } & (1) & (2) & (3) & (4) & (5) & (6) & (7) & (8) \\
\hline & \multicolumn{4}{|c|}{ Initial Major } & \multicolumn{4}{|c|}{ Earned Major } \\
\hline & $\begin{array}{c}0.0231 \\
(0.0080)^{*}\end{array}$ & $\begin{array}{l}-0.0048 \\
(0.0059)\end{array}$ & $\begin{array}{c}-0.0201 \\
(0.0042)^{* *}\end{array}$ & $\begin{array}{c}0.0086 \\
(0.0013)^{* * *}\end{array}$ & $\begin{array}{l}-0.0058 \\
(0.0065)\end{array}$ & $\begin{array}{c}-0.0253 \\
(0.0033) * * *\end{array}$ & $\begin{array}{c}-0.0384 \\
(0.0041)^{* * *}\end{array}$ & $\begin{array}{c}-0.0216 \\
(0.0029)^{* * *}\end{array}$ \\
\hline B. Females & $\begin{array}{c}0.0284 \\
(0.0043)^{* * *}\end{array}$ & $\begin{array}{c}0.0074 \\
(0.0051)\end{array}$ & $\begin{array}{l}-0.0046 \\
(0.0038)\end{array}$ & $\begin{array}{c}0.0121 \\
(0.0033)^{* *}\end{array}$ & $\begin{array}{c}0.0041 \\
(0.0050)\end{array}$ & $\begin{array}{c}-0.0121 \\
(0.0048)^{*}\end{array}$ & $\begin{array}{c}-0.0240 \\
(0.0049)^{* *}\end{array}$ & $\begin{array}{c}-0.0128 \\
(0.0023)^{* *}\end{array}$ \\
\hline C. Males & $\begin{array}{c}0.0181 \\
(0.0162)\end{array}$ & $\begin{array}{l}-0.0182 \\
(0.0086)\end{array}$ & $\begin{array}{c}-0.0343 \\
(0.0075)^{* *}\end{array}$ & $\begin{array}{c}0.0065 \\
(0.0024)^{*}\end{array}$ & $\begin{array}{l}-0.0180 \\
(0.0096)\end{array}$ & $\begin{array}{c}-0.0416 \\
(0.0025)^{* * *}\end{array}$ & $\begin{array}{c}-0.0538 \\
(0.0029) * * *\end{array}$ & $\begin{array}{c}-0.0321 \\
(0.0039)^{* * *}\end{array}$ \\
\hline Sex, Race/Ethnicity Dummies & Yes & Yes & Yes & Yes & Yes & Yes & Yes & Yes \\
\hline High School Dummies & Yes & Yes & Yes & Yes & Yes & Yes & Yes & Yes \\
\hline SAT Dummies & No & Yes & Yes & Yes & No & Yes & Yes & Yes \\
\hline High School GPA Dummies & No & No & Yes & Yes & No & No & Yes & Yes \\
\hline
\end{tabular}

Standard errors in parentheses are clustered by high school graduation year.

*Significant at $10 \%$ based on small sample t-distribution; **Significant at 5\%; ***Significant at $1 \%$. 
Table 9: Share of USG Graduates by Initial Major and Degree Major

\begin{tabular}{llcccc}
\hline & & \multicolumn{4}{c}{ Initial Major } \\
\cline { 3 - 6 } & & Undeclared & Non-STEM & STEM & Total \\
\hline Degree & Non-STEM & 0.342 & 0.381 & 0.080 & 0.803 \\
Major & STEM & 0.054 & 0.035 & 0.108 & 0.197 \\
& Total & 0.397 & 0.416 & 0.188 & 1.000 \\
\hline Degree & Non-STEM & 0.863 & 0.916 & 0.426 & \\
Major & STEM & 0.137 & 0.084 & 0.574 & \\
& Total & 1.000 & 1.000 & 1.000 & \\
\hline
\end{tabular}


Table 10: Effects of HOPE on Earning a STEM Degree by Initial Major

\begin{tabular}{lcccc}
\hline & $(1)$ & $(2)$ & $(3)$ & $(4)$ \\
& $\begin{array}{c}\text { Full } \\
\text { Sample }\end{array}$ & $\begin{array}{c}\text { Initial STEM } \\
\text { Majors }\end{array}$ & $\begin{array}{c}\text { Initial Non-STEM } \\
\text { Majors }\end{array}$ & $\begin{array}{c}\text { Initial Undeclared } \\
\text { Majors }\end{array}$ \\
\hline A. Total & -0.0253 & -0.0788 & -0.0098 & -0.0085 \\
& $(0.0033)^{* * *}$ & $(0.0151)^{* *}$ & $(0.0075)$ & $(0.0044)$ \\
& -0.0121 & -0.0633 & -0.0081 & -0.0053 \\
B. Females & $(0.0048)^{*}$ & $(0.0163)^{* *}$ & $(0.0040)$ & $(0.0047)$ \\
& & & & \\
& -0.0416 & -0.0937 & -0.0110 & -0.0138 \\
C. Males & $(0.0025)^{* * *}$ & $(0.0252)^{* *}$ & $(0.0162)$ & $(0.0062)$ \\
& & & & \\
Sex, Race, Ethnicity & Yes & Yes & Yes & Yes \\
High School Dummies & Yes & Yes & Yes & Yes \\
SAT Dummies & Yes & Yes & Yes & No \\
High School GPA Dummies & No & No & No & No \\
USG Institution Dummies & No & No & No & \\
\hline
\end{tabular}

Standard errors in parentheses are clustered by high school graduation year.

*Significant at $10 \%$ based on small sample t-distribution; **Significant at 5\%; ***Significant at $1 \%$. 
Table 11: Effects of HOPE on Earning a STEM Degree by Students' Initial Institutions

\begin{tabular}{|c|c|c|c|c|c|}
\hline & $\begin{array}{c}(1) \\
\text { Full } \\
\text { USG }\end{array}$ & $\begin{array}{l}\text { 4-Year } \\
\text { Schools }\end{array}$ & $\begin{array}{c}(3) \\
\text { 4-Year } \\
\text { Non- } \\
\text { Research }\end{array}$ & $\begin{array}{c}\text { Research } \\
\text { Universities }\end{array}$ & $\begin{array}{c}\text { Georgia } \\
\text { Tech }\end{array}$ \\
\hline A. Total & $\begin{array}{c}-0.0253 \\
(0.0033)^{* * *}\end{array}$ & $\begin{array}{c}-0.0284 \\
(0.0036)^{* * *}\end{array}$ & $\begin{array}{c}-0.0121 \\
(0.0033)^{* *}\end{array}$ & $\begin{array}{c}-0.0588 \\
(0.0084)^{* * *}\end{array}$ & $\begin{array}{c}-0.0944 \\
(0.0152)^{* * *}\end{array}$ \\
\hline B. Females & $\begin{array}{c}-0.0121 \\
(0.0048)^{*}\end{array}$ & $\begin{array}{c}-0.0145 \\
(0.0048)^{*}\end{array}$ & $\begin{array}{c}0.0015 \\
(0.0026)\end{array}$ & $\begin{array}{c}-0.0442 \\
(0.0093)^{* *}\end{array}$ & $\begin{array}{c}-0.1468 \\
(0.0045)^{* * *}\end{array}$ \\
\hline C. Males & $\begin{array}{c}-0.0416 \\
(0.0025)^{* * *}\end{array}$ & $\begin{array}{c}-0.0455 \\
(0.0027)^{* * *}\end{array}$ & $\begin{array}{c}-0.0331 \\
(0.0061)^{* *}\end{array}$ & $\begin{array}{c}-0.0679 \\
(0.0096)^{* * *}\end{array}$ & $\begin{array}{c}-0.0762 \\
(0.0171)^{* *}\end{array}$ \\
\hline Sex, Race, Ethnicity & Yes & Yes & Yes & Yes & Yes \\
\hline High School Dummies & Yes & Yes & Yes & Yes & Yes \\
\hline SAT Dummies & Yes & Yes & Yes & Yes & Yes \\
\hline High School GPA Dummies & No & No & No & No & No \\
\hline USG Institution Dummies & No & No & No & No & No \\
\hline
\end{tabular}

Standard errors in parentheses are clustered by high school graduation year.

*Significant at $10 \%$ based on small sample t-distribution; **Significant at 5\%; ***Significant at $1 \%$. 
Table 12: Effects of HOPE on Earning a STEM Degree by SAT Math Score for Initial STEM Majors

\begin{tabular}{|c|c|c|c|c|c|}
\hline & (1) & (2) & (3) & (4) & (5) \\
\hline SAT Math & $<400$ & $400-499$ & $500-599$ & $600-699$ & $700-800$ \\
\hline \multirow[t]{4}{*}{ A. Total } & -0.0295 & -0.0052 & -0.0678 & -0.0805 & -0.0585 \\
\hline & $(0.0280)$ & $(0.0176)$ & $(0.0141)^{* *}$ & $(0.0238)^{* *}$ & $(0.0168)^{* *}$ \\
\hline & {$[0.3438]$} & {$[0.3680]$} & {$[0.5539]$} & [0.7307] & {$[0.9020]$} \\
\hline & $\{-8.57 \%\}$ & $\{-1.41 \%\}$ & $\{-12.24 \%\}$ & $\{-11.02 \%\}$ & $\{-6.49 \%\}$ \\
\hline \multirow[t]{4}{*}{ B. Females } & 0.0157 & 0.0262 & -0.0321 & -0.0594 & -0.1134 \\
\hline & $(0.1091)$ & $(0.0312)$ & $(0.0056)^{* *}$ & $(0.0234)^{*}$ & $(0.0588)$ \\
\hline & {$[0.2987]$} & [0.2829] & {$[0.4571]$} & {$[0.6685]$} & [0.9608] \\
\hline & $\{5.24 \%\}$ & $\{9.26 \%\}$ & $\{-7.02 \%\}$ & $\{-8.89 \%\}$ & $\{-11.80 \%\}$ \\
\hline \multirow[t]{4}{*}{ C. Males } & -0.0128 & -0.0691 & -0.1169 & -0.0824 & -0.0409 \\
\hline & $(0.1790)$ & $(0.0621)$ & $(0.0278)^{* *}$ & $(0.0318)^{*}$ & $(0.0240)$ \\
\hline & [0.4118] & {$[0.4786]$} & {$[0.6324]$} & {$[0.7588]$} & {$[0.8902]$} \\
\hline & $\{-3.11 \%\}$ & $\{-14.44 \%\}$ & $\{-18.49 \%\}$ & $\{-10.86 \%\}$ & $\{-4.59 \%\}$ \\
\hline Sex, Race, Ethnicity & Yes & Yes & Yes & Yes & Yes \\
\hline High School Dummies & Yes & Yes & Yes & Yes & Yes \\
\hline SAT Dummies & Yes & Yes & Yes & Yes & Yes \\
\hline High School GPA Dummies & No & No & No & No & No \\
\hline USG Institution Dummies & No & No & No & No & No \\
\hline
\end{tabular}

Standard errors in parentheses are clustered by high school graduation year.

*Significant at $10 \%$ based on small sample t-distribution; **Significant at 5\%; ***Significant at $1 \%$. 
Table 13: Effects of HOPE on Earning a STEM Degree by First-Year GPA for Initial STEM Majors

\begin{tabular}{|c|c|c|c|c|c|c|}
\hline Freshman GPA & $\begin{array}{c}(1) \\
<2.50\end{array}$ & $\begin{array}{c}(2) \\
2.50-2.79\end{array}$ & $\begin{array}{c}(3) \\
2.80-2.99\end{array}$ & $\begin{array}{c}(4) \\
3.00-3.19\end{array}$ & $\begin{array}{c}(5) \\
3.20-3.49\end{array}$ & $\begin{array}{c}(6) \\
3.50-4.00\end{array}$ \\
\hline A. Total & $\begin{array}{c}-0.0718 \\
(0.0322) \\
{[0.4869]} \\
\{-14.75 \%\}\end{array}$ & $\begin{array}{c}-0.1449 \\
(0.0281)^{* *} \\
{[0.6327]} \\
\{-22.90 \%\}\end{array}$ & $\begin{array}{c}-0.0632 \\
(0.0563) \\
{[0.6311]} \\
\{-10.01 \%\}\end{array}$ & $\begin{array}{c}-0.0878 \\
(0.0131)^{* * *} \\
{[0.6695]} \\
\{-13.11 \%\}\end{array}$ & $\begin{array}{l}-0.0321 \\
(0.0143) \\
{[0.7177]} \\
\{-4.47 \%\}\end{array}$ & $\begin{array}{c}-0.1027 \\
(0.0139) * * * \\
{[0.8088]} \\
\{-12.70 \%\}\end{array}$ \\
\hline B. Females & $\begin{array}{c}-0.0394 \\
(0.0456) \\
{[0.3559]} \\
\{-11.07 \%\}\end{array}$ & $\begin{array}{c}-0.1306 \\
(0.0820) \\
{[0.4656]} \\
\{-28.05 \%\}\end{array}$ & $\begin{array}{c}-0.1085 \\
(0.0826) \\
{[0.5278]} \\
\{-20.56 \%\}\end{array}$ & $\begin{array}{c}-0.1629 \\
(0.0726) \\
{[0.5577]} \\
\{-29.21 \%\}\end{array}$ & $\begin{array}{c}0.0411 \\
(0.0417) \\
{[0.5724]} \\
\{7.18 \%\}\end{array}$ & $\begin{array}{c}-0.0704 \\
(0.0141)^{* *} \\
{[0.7238]} \\
\{-9.73 \%\}\end{array}$ \\
\hline C. Males & $\begin{array}{c}-0.0858 \\
(0.0404) \\
{[0.5695]} \\
\{-15.07 \%\}\end{array}$ & $\begin{array}{c}-0.1356 \\
(0.0568) * \\
{[0.7310]} \\
\{-18.55 \%\}\end{array}$ & $\begin{array}{l}-0.0483 \\
(0.0658) \\
{[0.7132]} \\
\{-6.77 \%\}\end{array}$ & $\begin{array}{c}-0.0950 \\
(0.0148) * * * \\
{[0.7576]} \\
\{-12.54 \%\}\end{array}$ & $\begin{array}{c}-0.1114 \\
(0.0308)^{* *} \\
{[0.8106]} \\
\{-13.74 \%\}\end{array}$ & $\begin{array}{c}-0.1247 \\
(0.0248)^{* *} \\
{[0.8650]} \\
\{-14.42 \%\}\end{array}$ \\
\hline Sex, Race, Ethnicity & Yes & Yes & Yes & Yes & Yes & Yes \\
\hline High School Dummies & Yes & Yes & Yes & Yes & Yes & Yes \\
\hline SAT Dummies & Yes & Yes & Yes & Yes & Yes & Yes \\
\hline High School GPA Dummies & No & No & No & No & No & No \\
\hline USG Institution Dummies & No & No & No & No & No & No \\
\hline
\end{tabular}

Standard errors in parentheses are clustered by high school graduation year.

*Significant at $10 \%$ based on small sample t-distribution; **Significant at 5\%; ***Significant at $1 \%$. 
Table 14: Effects of HOPE on First-Year GPA

(1) Graduates

\begin{abstract}
A. Total
\end{abstract}
0.1793

$(0.0119)^{* * * *}$

B. Females

0.1928

$(0.0118)^{* * * *}$

C. Males
(2)

(3)

Initial STEM

Initial STEM Majors

0.1290

$(0.0120)^{* * *}$

0.1467

$(0.0247) * * *$

0.1074

$(0.0129)^{* * *}$

$(0.0146)^{* * * *}$

Yes

Yes

Yes

No

No

Majors Earning TEM Degrees

(4)

Initial STEM

Majors Earning

Non-STEM Degrees

Sex, Race, Ethnicity

High School Dummies

SAT Dummies

High School GPA Dummies

USG Institution Dummies

Standard errors in parentheses are clustered by high school graduation year.

*Significant at $10 \%$ based on small sample t-distribution; **Significant at 5\%; ***Significant at $1 \%$. 
Table 15: HOPE Program Effects on Non-STEM Earned Majors

\begin{tabular}{|c|c|c|c|c|c|}
\hline & $\begin{array}{c}\text { (1) } \\
\text { Business }\end{array}$ & $\begin{array}{c}\text { (2) } \\
\text { Education }\end{array}$ & $\begin{array}{c}(3) \\
\text { Health }\end{array}$ & $\begin{array}{c}\text { (4) } \\
\text { Liberal Arts }\end{array}$ & $\begin{array}{c}(5) \\
\text { Social } \\
\text { Sciences }\end{array}$ \\
\hline \multicolumn{6}{|l|}{ Full Sample: } \\
\hline A. Total & $\begin{array}{c}0.0494 \\
(0.0025) * * *\end{array}$ & $\begin{array}{c}-0.0282 \\
(0.0037)^{* * * *}\end{array}$ & $\begin{array}{c}0.0045 \\
(0.0017)^{*}\end{array}$ & $\begin{array}{c}0.0101 \\
(0.0052)\end{array}$ & $\begin{array}{c}-0.0105 \\
(0.0032)^{* *}\end{array}$ \\
\hline B. Females & $\begin{array}{c}0.0238 \\
(0.0043)^{* *}\end{array}$ & $\begin{array}{c}-0.0417 \\
(0.0052)^{* * *}\end{array}$ & $\begin{array}{c}0.0094 \\
(0.0022) * *\end{array}$ & $\begin{array}{c}0.0163 \\
(0.0040)^{* *}\end{array}$ & $\begin{array}{c}0.0042 \\
(0.0014)^{*}\end{array}$ \\
\hline C. Males & $\begin{array}{c}0.0797 \\
(0.0063)^{* * *}\end{array}$ & $\begin{array}{c}-0.0072 \\
(0.0026)^{*}\end{array}$ & $\begin{array}{l}-0.0013 \\
(0.0009)\end{array}$ & $\begin{array}{l}-0.0008 \\
(0.0068)\end{array}$ & $\begin{array}{c}-0.0288 \\
(0.0062)^{* *}\end{array}$ \\
\hline Sex, Race, Ethnicity & Yes & Yes & Yes & Yes & Yes \\
\hline High School Dummies & Yes & Yes & Yes & Yes & Yes \\
\hline SAT Dummies & Yes & Yes & Yes & Yes & Yes \\
\hline High School GPA Dummies & No & No & No & No & No \\
\hline USG Institution Dummies & No & No & No & No & No \\
\hline \multicolumn{6}{|l|}{ Initial STEM Majors: } \\
\hline A. Total & $\begin{array}{c}0.0579 \\
(0.0138)^{* *}\end{array}$ & $\begin{array}{l}-0.0015 \\
(0.0043)\end{array}$ & $\begin{array}{c}0.0079 \\
(0.0048)\end{array}$ & $\begin{array}{c}0.0121 \\
(0.0039)^{*}\end{array}$ & $\begin{array}{c}0.0024 \\
(0.0038)\end{array}$ \\
\hline B. Females & $\begin{array}{c}0.0334 \\
(0.0160)\end{array}$ & $\begin{array}{l}-0.0147 \\
(0.0071)\end{array}$ & $\begin{array}{c}0.0134 \\
(0.0156)\end{array}$ & $\begin{array}{c}0.0120 \\
(0.0015) * * *\end{array}$ & $\begin{array}{c}0.0192 \\
(0.0106)\end{array}$ \\
\hline C. Males & $\begin{array}{c}0.0768 \\
(0.0222)^{* *}\end{array}$ & $\begin{array}{c}0.0061 \\
(0.0018)^{* *}\end{array}$ & $\begin{array}{c}0.0033 \\
(0.0011)^{*}\end{array}$ & $\begin{array}{c}0.0099 \\
(0.0091)\end{array}$ & $\begin{array}{l}-0.0024 \\
(0.0030)\end{array}$ \\
\hline
\end{tabular}

Standard errors in parentheses are clustered by high school graduation year.

*Significant at $10 \%$ based on small sample t-distribution; **Significant at 5\%; ***Significant at $1 \%$. 
Table A: Merit Program Effects on Bachelor's Degree Completion

\begin{tabular}{|c|c|c|c|c|c|}
\hline & $(1)$ & $(2)$ & (3) & (4) & $(5)$ \\
\hline \multirow{3}{*}{ A. Total Population } & -0.0047 & -0.0045 & -0.0055 & -0.0059 & -0.0003 \\
\hline & $(0.0052)$ & $(0.0051)$ & $(0.0049)$ & $(0.0046)$ & $(0.0031)$ \\
\hline & {$\left[\begin{array}{ll}-0.0105 & 0.0012\end{array}\right]$} & {$\left[\begin{array}{ll}-0.0118 & 0.0004\end{array}\right]$} & [N/A] & [N/A] & {$\left[\begin{array}{ll}-0.0071 & 0.0065\end{array}\right]$} \\
\hline \multirow[t]{3}{*}{ B. Females } & -0.0051 & -0.0059 & -0.0069 & -0.0093 & 0.0010 \\
\hline & $(0.0059)$ & $(0.0062)$ & $(0.0066)$ & $(0.0060)$ & $(0.0039)$ \\
\hline & {$\left[\begin{array}{lll}-0.0137 & 0.0044]\end{array}\right]$} & {$\left[\begin{array}{ll}-0.0153 & 0.0024\end{array}\right]$} & [N/A] & {$[\mathrm{N} / \mathrm{A}]$} & {$\left[\begin{array}{ll}-0.0088 & 0.0137\end{array}\right]$} \\
\hline \multirow[t]{3}{*}{ C. Males } & -0.0039 & -0.0029 & -0.0038 & -0.0025 & -0.0015 \\
\hline & $(0.0071)$ & $(0.0072)$ & $(0.0066)$ & $(0.0068)$ & $(0.0046)$ \\
\hline & {$\left[\begin{array}{ll}-0.0141 & 0.0052\end{array}\right]$} & {$\left[\begin{array}{ll}-0.0144 & 0.0046\end{array}\right]$} & {$[\mathrm{N} / \mathrm{A}]$} & {$[\mathrm{N} / \mathrm{A}]$} & {$\left[\begin{array}{ll}-0.0113 & 0.0089\end{array}\right]$} \\
\hline State of Birth Dummies & Yes & Yes & Yes & Yes & Yes \\
\hline Year of Birth Dummies & Yes & Yes & Yes & Yes & Yes \\
\hline Age Dummies & Yes & Yes & Yes & Yes & Yes \\
\hline Sex, Race/Ethnicity & Yes & Yes & Yes & Yes & Yes \\
\hline State of Birth*Year Trends & Yes & Yes & Yes & Yes & Yes \\
\hline Region*Year Dummies & No & No & Yes & No & No \\
\hline Strong Merit States & Treatment & Treatment & Treatment & Treatment & Treatment \\
\hline Weak Merit States & Excluded & Control & Excluded & Excluded & Treatment \\
\hline Non-Merit States & Control & Control & Control & Excluded & Control \\
\hline Total States & 33 & 51 & 33 & 9 & 51 \\
\hline
\end{tabular}

Notes: Standard errors in parentheses are clustered by state of birth. Conley-Taber 95\% confidence intervals are in brackets; these are inestimable for columns 3 and 4 because of how the control group is specified. 
Table B: Merit Effects on STEM Degrees for Different Sample Restrictions by Education Level

\begin{tabular}{|c|c|c|c|c|}
\hline Education Sample Restriction: & $\begin{array}{l}\text { All } \\
(1)\end{array}$ & $\begin{array}{l}\text { High School+ } \\
\text { (2) }\end{array}$ & $\begin{array}{c}\text { Some College+ } \\
\text { (3) }\end{array}$ & $\begin{array}{c}\text { Bachelor's+ } \\
\text { (4) }\end{array}$ \\
\hline A. Total Population & $\begin{array}{c}-0.0042 \\
(0.0018)^{* *} \\
{[-0.0082-0.0011]}\end{array}$ & $\begin{array}{c}-0.0040 \\
(0.0019)^{* *} \\
{[-0.0081 \quad-0.0004]}\end{array}$ & $\begin{array}{c}-0.0082 \\
(0.0033)^{* *} \\
{[-0.0148 \quad-0.0025]}\end{array}$ & $\begin{array}{c}-0.0133 \\
(0.0053)^{* *} \\
{[-0.0261 \quad-0.0049]}\end{array}$ \\
\hline Pre-merit Mean in Strong States & 0.054 & 0.060 & 0.101 & 0.206 \\
\hline$\%$ Decrease in Number of STEM & $-7.82 \%$ & $-6.67 \%$ & $-8.12 \%$ & $-6.45 \%$ \\
\hline B. Females & $\begin{array}{c}-0.0021 \\
(0.0031) \\
{[-0.00630 .0025]}\end{array}$ & $\begin{array}{c}-0.0022 \\
(0.0033) \\
{[-0.00590 .0022]}\end{array}$ & $\begin{array}{c}-0.0040 \\
(0.0050) \\
{[-0.00980 .0024]}\end{array}$ & $\begin{array}{c}-0.0057 \\
(0.0093) \\
{[-0.01720 .0090]}\end{array}$ \\
\hline Pre-merit Mean in Strong States & 0.039 & 0.043 & 0.066 & 0.135 \\
\hline$\%$ Decrease in Number of STEM & $-5.36 \%$ & $-5.14 \%$ & $-6.02 \%$ & $-4.22 \%$ \\
\hline C. Males & $\begin{array}{c}-0.0063 \\
(0.0026)^{* *} \\
{[-0.0124-0.0018]}\end{array}$ & $\begin{array}{c}-0.0059 \\
(0.0030)^{*} \\
{[-0.0121 \quad-0.0002]}\end{array}$ & $\begin{array}{c}-0.0135 \\
(0.0059)^{* *} \\
{[-0.0244 \quad-0.0036]}\end{array}$ & $\begin{array}{c}-0.0240 \\
(0.0099)^{* *} \\
{[-0.0468-0.0104]}\end{array}$ \\
\hline Pre-merit Mean in Strong States & 0.069 & 0.078 & 0.145 & 0.298 \\
\hline$\%$ Decrease in Number of STEM & $-9.19 \%$ & $-7.54 \%$ & $-9.30 \%$ & $-8.05 \%$ \\
\hline State of Birth Dummies & Yes & Yes & Yes & Yes \\
\hline Year of Birth Dummies & Yes & Yes & Yes & Yes \\
\hline Age Dummies & Yes & Yes & Yes & Yes \\
\hline Sex, Race/ Ethnicity Dummies & Yes & Yes & Yes & Yes \\
\hline State of Birth*Year Trends & Yes & Yes & Yes & Yes \\
\hline Strong Merit States & Treatment & Treatment & Treatment & Treatment \\
\hline Weak Merit States & Excluded & Excluded & Excluded & Excluded \\
\hline Non-Merit States & Control & Control & Control & Control \\
\hline
\end{tabular}

Notes: Standard errors in parentheses are clustered by state of birth. Conley-Taber $95 \%$ confidence intervals are in brackets.

*Significant at $10 \%$ based on standard errors clustered by state of birth; **Significant at $5 \%$. 
Table C: USG Cohort Year Dummy Coefficients

\begin{tabular}{lcc}
\hline Outcome: & Initial STEM Major & STEM Degree \\
\hline A. Total Population & & \\
1991 Cohort Dummy & 0.0044 & 0.0053 \\
& $(0.0054)$ & $(0.0053)$ \\
1995 Cohort Dummy & -0.0084 & -0.0227 \\
& $(0.0054)$ & $(0.0053)^{* * *}$ \\
1996 Cohort Dummy & 0.0032 & -0.0222 \\
& $(0.0053)$ & $(0.0053)^{* * *}$ \\
B. Females & & \\
1991 Cohort Dummy & & 0.0062 \\
& -0.0028 & $(0.0062)$ \\
1995 Cohort Dummy & $(0.0067)$ & -0.0091 \\
1996 Cohort Dummy & 0.0013 & $(0.0061)$ \\
& $(0.0066)$ & -0.0082 \\
C. Males & 0.0102 & $(0.0061)$ \\
1991 Cohort Dummy & $(0.0065)$ & \\
1995 Cohort Dummy & & 0.0059 \\
1996 Cohort Dummy & 0.0130 & $(0.0092)$ \\
& $(0.0088)$ & -0.0381 \\
\hline
\end{tabular}

Note: 1990 is the omitted based year. Other specifications correspond to columns 2 and 6 of Table 8. OLS Standard errors are in parentheses. ${ }^{* *}$ Significant at $5 \% ; * * *$ Significant at $1 \%$. 